\title{
Analysis of fixed bed data for the extraction of a rate mechanism for the reaction of hematite with methane.
}

\author{
Ronald W. Breault ${ }^{\mathrm{a}, 1}$ and Esmail R. Monazam ${ }^{\mathrm{a}, \mathrm{b}}$ \\ ${ }^{a}$ National Energy Technology Laboratory \\ U. S. Department of Energy \\ 3610 Collins Ferry Rd. \\ Morgantown, West Virginia 26507-0880 \\ ${ }^{\mathrm{b}}$ REM Engineering Services, PLLC \\ 3537 Collins Ferry Rd. \\ Morgantown, West Virginia 26505
}

\begin{abstract}
Chemical looping combustion is a promising technology for the capture of $\mathrm{CO}_{2}$ involving redox materials as oxygen carriers. The effects of reduction conditions, namely, temperature and fuel partial pressure on the conversion products are investigated. The experiments were conducted in a laboratory fixed-bed reactor that was operated cyclically with alternating reduction and oxidation periods. Reactions are assumed to occur in the shell surrounding the particle grains with diffusion of oxygen to the surface from the grain core. Activation energies for the shell and core reactions range from 9 to $209 \mathrm{~kJ} / \mathrm{mol}$ depending on the reaction step.
\end{abstract}

\section{Introduction}

Carbon dioxide $\left(\mathrm{CO}_{2}\right)$ emissions have been identified as a possible reason for climate changes and to address this issue, the U.S. Department of Energy has set goals for carbon capture systems at $90 \%$ carbon dioxide $\left(\mathrm{CO}_{2}\right)$ capture with less than a 35\% increase in cost of electricity [1]. There are four main categories of $\mathrm{CO}_{2}$ control technologies that can achieve $90 \%$ carbon dioxide $\left(\mathrm{CO}_{2}\right)$ capture with less than a 35\% increase in cost of electricity. These are pre-combustion, post-combustion, oxy-fuel and chemical looping [2]. The work presented in this paper looks into the performance of a fixed bed chemical looping system.

The term "chemical looping" is a relatively new name to an old concept that was utilized in the early 1900s for the coal gasification technology called the Steam-Iron Process and again in the late 1960s and early 1970s for another gasification technology which was called the $\mathrm{CO}_{2}$ Acceptor Process [3]. This "chemical looping" terminology was introduced in the 1990s to refer to a cyclic processes in which an oxygen rich solid was contacted with a fuel to reduce the oxygen rich solid forming carbon dioxide and

\footnotetext{
${ }^{1}$ Corresponding author, ronald.breault@ netl.doe.gov; 304-285-4486;

US DOE/NETL, PO Box 880, Morgantown, WV 26507 
water (combustion products). The reduced solid could then be transferred to another vessel and reoxidized. The cycling of the oxygen carrier between the oxidizer and reducer vessels is now termed chemical looping combustion.

Chemical looping combustion is being investigated around the world for power production because the technology allows for fuel conversion with easy $\mathrm{CO}_{2}$ separation $[4,5,6]$. The current investigation is aimed at evaluating hematite, a naturally occurring $\mathrm{Fe}_{2} \mathrm{O}_{3}$ ore, as an oxygen carrier for natural gas fueled applications. $\mathrm{Fe}_{2} \mathrm{O}_{3}$ has been cited as a potential carrier in numerous research publications [4-26] with many of these focusing on the development of required kinetics from TGA experimental investigations for scale-up of this technology.

Methane reacts with iron oxide (hematite) to ultimately produce a mixture of carbon dioxide, water, carbon monoxide, hydrogen and various reduced states of iron oxide from magnatite to iron. This complex process has been extensive investigated both for the production of steel but most recently for use of the hematite as an oxygen carrier in chemical looping processes [8-26] but even so, questions regarding the rate mechanism still exist. Symbolically, the reaction can be written as the unbalanced expression:

$$
\mathrm{CH}_{4}+\mathrm{Fe}_{2} \mathrm{O}_{3} \rightarrow \mathrm{CO}_{2}+\mathrm{H}_{2} \mathrm{O}+\mathrm{CO}+\mathrm{H}_{2}+\mathrm{Fe}_{3} \mathrm{O}_{4}+\mathrm{FeO}+\mathrm{Fe}
$$

The above expression is the result of many reactions, some of which are identified below:

$$
\begin{aligned}
& \mathrm{CH}_{4}+3 \mathrm{Fe}_{2} \mathrm{O}_{3} \rightarrow \mathrm{CO}+2 \mathrm{H}_{2}+2 \mathrm{Fe}_{3} \mathrm{O}_{4} \\
& \mathrm{CH}_{4}+\mathrm{Fe}_{2} \mathrm{O}_{3} \rightarrow \mathrm{CO}+2 \mathrm{H}_{2}+2 \mathrm{FeO} \\
& 2 \mathrm{CH}_{4}+2 \mathrm{Fe}_{3} \mathrm{O}_{4} \rightarrow 2 \mathrm{CO}+4 \mathrm{H}_{2}+6 \mathrm{FeO} \\
& \mathrm{CH}_{4}+4 \mathrm{FeO} \rightarrow \mathrm{CO}+2 \mathrm{H}_{2}+4 \mathrm{Fe} \\
& \mathrm{CO}+\mathrm{Fe}_{2} \mathrm{O}_{3} \rightarrow \mathrm{CO}_{2}+2 \mathrm{FeO} \\
& \mathrm{H}_{2}+\mathrm{Fe}_{2} \mathrm{O}_{3} \rightarrow \mathrm{H}_{2} \mathrm{O}+2 \mathrm{FeO} \\
& \mathrm{CO}+\mathrm{Fe}_{3} \mathrm{O}_{4} \rightarrow \mathrm{CO}_{2}+3 \mathrm{FeO} \\
& \mathrm{H}_{2}+\mathrm{Fe}_{3} \mathrm{O}_{4} \rightarrow \mathrm{H} 2 \mathrm{O}+3 \mathrm{FeO}
\end{aligned}
$$

To further complicate the reaction mechanism, there is the significance that the reactions are all heterogeneous with the solid phase reacting and being consumed with time. This creates a moving reaction front within the solid phase (particle).

Researchers have modeled the processes in the above reactions with first order Arrhenius type reaction rate expressions and with more complicated nucleation and growth expressions, see Abad [8] and Lou [23], respectively. Most recently, Breault and Monazam [27] have analyzed the behavior of hematite in a fixed bed reactor with methane as the reducing gas. They found that the hematite particles reacted as a fixed thickness shell giving up oxygen rapidly and a core diffusing oxygen to the shell surface. They also found that the available oxygen in the fast reacting shell decreased with the cumulative time a particle 
spent at high temperature when the fixed bed reactor was cycled between reduction and oxidation. This particular work focuses on a more in depth analysis of the first reduction cycle as the experimental data from all the cyclic fluidized bed experiments mimic the first cycle results from the fixed bed tests.

Numerous researchers are investigating various naturally occurring and manufactured iron oxide based carriers. These are summarized in Tables 1. In Table 1, of particular interest is the work of Abad and colleagues [9], as they have put forward the most advanced and complete model for the reduction of ilmenite. Ilmenite is a naturally occurring iron and titanium mineral in the form of $\mathrm{FeTiO}_{3}$. The actual material tests by Abad et al. [9] consisted of $94.3 \%$ ilmenite with the balance being rutile $\left(\mathrm{TiO}_{2}\right)$ and Hematite $\left(\mathrm{Fe}_{2} \mathrm{O}_{3}\right)$. The material had a Fe to Ti ratio of approximately 1 . Monazam et al. have been exploring the kinetics of North American iron containing ores, primarily hematite from Canada [20, 23 and 24]. Monazam et al. [20] found the reaction of methane with the Canadian hematite to occur with a two reaction mechanism. The other authors [11-19, $21 \& 22]$, work primarily with $\mathrm{Fe}_{2} \mathrm{O}_{3}$-support/binder mixtures. Furthermore, most use steam or at least humidified $\mathrm{CH}_{4}$ to inhibit coke formation due to the $\mathrm{CH}_{4}$ cracking. In general, the rate improved in these studies as the initial fabricated particle became conditioned after several cycles. This is in the opposite direction with the current study which is discussed below for the naturally occurring Canadian hematite. Also, with regard to Table 1, Go et al. [13] found the reaction with $\mathrm{Fe}_{2} \mathrm{O}_{3}$ and methane to be diffusion controlled. That work used the smallest sample size reported. Also, Johansson et al. [15] found that materials that had seen high temperatures were diffusion controlled. Lou et al. [23] found that the activation energy ranged between 49 and $184 \mathrm{~kJ} / \mathrm{mol}$ depending on the whether the $\mathrm{Fe}_{2} \mathrm{O}_{3}$ was synthetic or iron ore, respectively. Zhang et al [24] looked ultralow $\mathrm{CH}_{4}$ levels $(<1 \%)$ simulating mine vents. Forutan et al. [25] provides a good head to head comparison of different carrier performances with iron oxide showing the greatest resistance to sintering. $\mathrm{Ku}$ et al. [26] observed carbon deposition as seen in the gas composition during regeneration at 900C indicative of coke formation from the cracking of the methane. 
Table 1. Summary of iron oxide reduction with methane

\begin{tabular}{|c|c|c|c|c|c|c|c|c|}
\hline Author & Reactor Type & $\begin{array}{c}\text { Sample } \\
\text { Size (mg) }\end{array}$ & $\begin{array}{l}\text { Particle } \\
\text { Size } \\
(\mu \mathrm{m})\end{array}$ & $\begin{array}{c}\text { BET } \\
\text { Surface } \\
\text { Area } \\
\left(\mathrm{m}^{2} / \mathrm{g}\right)\end{array}$ & $\begin{array}{c}\text { Sample } \\
\text { Frequency } \\
(\mathrm{Hz})\end{array}$ & Reduction Gas & $\begin{array}{c}\text { Reaction } \\
\text { Control }\end{array}$ & Carrie Form \\
\hline $\begin{array}{l}\text { Abad et al. } \\
(2007)[8]\end{array}$ & $\begin{array}{l}\text { Circulating } \\
\text { bed }\end{array}$ & 110,000 & $\begin{array}{c}90 \\
\text { to } \\
212\end{array}$ & - & - & $\begin{array}{l}\text { Natural gas } \\
\left(88 \% \mathrm{CH}_{4}\right)\end{array}$ & - & $\begin{array}{c}60 \% \mathrm{Fe}_{2} \mathrm{O}_{3} \\
\text { and } \mathrm{Al}_{2} \mathrm{O}_{3}\end{array}$ \\
\hline $\begin{array}{l}\text { Abad et al. } \\
\text { (2011) [9] }\end{array}$ & TGA & 50 & $\begin{array}{c}150 \\
\text { to } \\
300\end{array}$ & .8 & - & $\begin{array}{c}\mathrm{CH}_{4} \text { and } \\
\text { steam }\end{array}$ & $\begin{array}{c}\text { Shrinking } \\
\text { grain }\end{array}$ & $\begin{array}{l}\text { FeTiO3 } \\
\text { (Ilmenite }\end{array}$ \\
\hline $\begin{array}{c}\text { Adanez et al. } \\
\text { (2005) [10] }\end{array}$ & $\begin{array}{c}\text { Bubbling } \\
\text { fluidized bed }\end{array}$ & $2 \times 10^{5}$ & $\begin{array}{c}100 \\
\text { to } \\
300\end{array}$ & - & - & $\begin{array}{c}\mathrm{CH}_{4} \text { saturated } \\
\text { with } \mathrm{H}_{2} \mathrm{O} \\
\text { vapor }\end{array}$ & - & $\begin{array}{l}60 \% \mathrm{Fe}_{2} \mathrm{O}_{3} \\
\text { and } \mathrm{Al}_{2} \mathrm{O}_{3}\end{array}$ \\
\hline $\begin{array}{l}\text { Cho et al. } \\
(2002)[11]\end{array}$ & $\begin{array}{c}\text { Bubbling } \\
\text { fluidized bed }\end{array}$ & $\begin{array}{c}15,000 \text { to } \\
60,000\end{array}$ & 125 to 250 & - & - & $\mathrm{CH}_{4}$ & - & $\begin{array}{c}\mathrm{Fe}_{2} \mathrm{O}_{3} \text { and } \\
\mathrm{Al}_{2} \mathrm{O}_{3}\end{array}$ \\
\hline $\begin{array}{l}\text { Gayán et al. } \\
\text { (2012)[12] }\end{array}$ & $\begin{array}{c}\text { Bubbling } \\
\text { fluidized bed }\end{array}$ & $2 \times 10^{5}$ & $\begin{array}{c}100 \\
\text { to } \\
300\end{array}$ & 9.3 & - & $\mathrm{CH}_{4}$ in $\mathrm{N}_{2}$ & - & $\begin{array}{c}\mathrm{Fe}_{2} \mathrm{O}_{3} \text { on } \\
\mathrm{Al}_{2} \mathrm{O}_{3}\end{array}$ \\
\hline $\begin{array}{l}\text { Go et al. } \\
(2008)[13]\end{array}$ & TGA & 7 to 8 & 125 & 9.055 & 0.033 & $\mathrm{CH}_{4}$ & Diffusion & $\mathrm{Fe}_{2} \mathrm{O}_{3}$ \\
\hline $\begin{array}{l}\text { He et al. } \\
(2007)[14]\end{array}$ & Fixed Bed & 60,000 & $\begin{array}{c}1500 \\
\text { to } \\
2000\end{array}$ & - & - & $\begin{array}{c}\text { Humidified } \\
\mathrm{CH}_{4} \text { in } \mathrm{Ar}\end{array}$ & - & $\begin{array}{l}80 \% \mathrm{Fe}_{2} \mathrm{O}_{3} \\
\text { and } \mathrm{Al}_{2} \mathrm{O}_{3}\end{array}$ \\
\hline $\begin{array}{l}\text { Johansson et } \\
\text { al. (2004) [15] }\end{array}$ & $\begin{array}{c}\text { Bubbling } \\
\text { fluidized bed }\end{array}$ & $\begin{array}{c}10,000 \\
\text { and } \\
15,000\end{array}$ & $\begin{array}{c}125 \\
\text { to } \\
180\end{array}$ & - & - & $\begin{array}{c}\mathrm{CH}_{4} \text { and } \\
\text { steam }\end{array}$ & $\begin{array}{l}\text { Diffusion for } \\
\text { materials } \\
\text { that have } \\
\text { seen high } \\
\text { temperatures }\end{array}$ & $\begin{array}{l}\mathrm{Fe}_{2} \mathrm{O}_{3} \text { on } \\
\mathrm{MgAl}_{2} \mathrm{O}_{4}\end{array}$ \\
\hline $\begin{array}{l}\text { Leion et al. } \\
\text { (2008) [16] }\end{array}$ & $\begin{array}{c}\text { Bubbling } \\
\text { fluidized bed }\end{array}$ & 15,000 & $\begin{array}{c}125 \\
\text { to } \\
180\end{array}$ & - & - & $\mathrm{CH}_{4}$ & - & $\begin{array}{c}\mathrm{FeTiO3} \\
\text { (Ilmenite) }\end{array}$ \\
\hline $\begin{array}{l}\text { Mattisson et } \\
\text { al. (2004) [17] }\end{array}$ & $\begin{array}{c}\text { Bubbling } \\
\text { fluidized bed }\end{array}$ & 10,000 & $\begin{array}{c}125 \\
\text { to } \\
180\end{array}$ & - & - & $\begin{array}{c}\mathrm{CH}_{4} \text { and } \\
\text { steam }\end{array}$ & $\begin{array}{l}\text { Kinetic to } \\
\text { Diffusion }\end{array}$ & $\begin{array}{c}60 \% \mathrm{Fe}_{2} \mathrm{O}_{3} \\
\text { and } \mathrm{Al}_{2} \mathrm{O}_{3}\end{array}$ \\
\hline $\begin{array}{c}\text { Mendiara et al. } \\
\text { (2012) [18] }\end{array}$ & $\begin{array}{c}\text { Bubbling } \\
\text { fluidized bed }\end{array}$ & $3 \times 10^{5}$ & $\begin{array}{c}150 \\
\text { to } \\
300\end{array}$ & .9 & - & $\begin{array}{c}\mathrm{CH}_{4} \text { and } \\
\text { steam in } \mathrm{N}_{2}\end{array}$ & - & $\begin{array}{l}71 \% \mathrm{Fe}_{2} \mathrm{O}_{3} \\
\text { and } \mathrm{Al}_{2} \mathrm{O}_{3}\end{array}$ \\
\hline $\begin{array}{l}\text { Moghtaderi et } \\
\text { al. (2010) [19] }\end{array}$ & TGA & 28 to 40 & 30 to 40 & 3.5 & 1 & $\begin{array}{c}\mathrm{CH}_{4} \text { and } \\
\text { steam }\end{array}$ & - & $\mathrm{Fe}_{2} \mathrm{O}_{3}$ \\
\hline $\begin{array}{l}\text { Monazam et } \\
\text { al. (2013) [20] }\end{array}$ & TGA & 60 & & .1 & 1 & $\mathrm{CH}_{4}$ in $\mathrm{N}_{2}$ & $\begin{array}{l}\text { Kinetic and } \\
\text { Diffusion } \\
\text { (JMA) }\end{array}$ & $\mathrm{Fe}_{2} \mathrm{O}_{3}$ \\
\hline $\begin{array}{c}\text { Son et al. } \\
(2006)[21]\end{array}$ & $\begin{array}{l}\text { Circulating } \\
\text { bed }\end{array}$ & $6 \times 10^{5}$ & $\begin{array}{c}106 \\
\text { to } \\
150\end{array}$ & - & 0.04 & $\mathrm{CH}_{4}$ & - & $\begin{array}{c}\mathrm{Fe}_{2} \mathrm{O}_{3} \text { on } \\
\mathrm{TiO}_{2}, \mathrm{Al}_{2} \mathrm{O}_{3} \\
\text { and bentonite }\end{array}$ \\
\hline $\begin{array}{l}\text { J. Zhang et al. } \\
\text { (2012) [22] }\end{array}$ & TGA & - & - & 4 & - & $\mathrm{CH}_{4}$ & - & $\begin{array}{l}75 \% \mathrm{Fe}_{2} \mathrm{O}_{3} \\
\text { and } \mathrm{Al}_{2} \mathrm{O}_{3}\end{array}$ \\
\hline $\begin{array}{c}\text { Lou et al. } \\
\text { (2014) [23] }\end{array}$ & TGA & 10 & 100 to 200 & 0.075 & - & $\mathrm{CH}_{4}$ and $\mathrm{CO}_{2}$ & JMA & $\mathrm{Fe}_{2} \mathrm{O}_{3}$ \\
\hline $\begin{array}{l}\text { Y. Zhang et al. } \\
\text { (2014) [24] }\end{array}$ & TGA & 10 to 15 & 75 to 150 & - & - & $\mathrm{CH}_{4}$ in $\mathrm{N}_{2}$ & - & $\begin{array}{c}\mathrm{Fe}_{2} \mathrm{O}_{3} \text { and } \\
\mathrm{Al}_{2} \mathrm{O}_{3}\end{array}$ \\
\hline $\begin{array}{c}\text { Forutan et al. } \\
\text { (2014) [25] }\end{array}$ & $\begin{array}{c}\text { Fixed bed } \\
\text { micro reactor }\end{array}$ & 2100 & 400 to 841 & 1.232 & - & $\mathrm{CH}_{4}$ & - & $\begin{array}{c}40 \% \mathrm{Fe}_{2} \mathrm{O}_{3} \\
\text { on } \mathrm{Al}_{2} \mathrm{O}_{3}\end{array}$ \\
\hline $\begin{array}{c}\text { Ku et al. } \\
\text { (2014) [26] }\end{array}$ & Fixed bed & $2.9 \times 10^{6}$ & - & - & & $\mathrm{CH}_{4}$ in $\mathrm{N}_{2}$ & - & $\begin{array}{c}\mathrm{Fe}_{2} \mathrm{O}_{3} \text { and } \\
\mathrm{Al}_{2} \mathrm{O}_{3}\end{array}$ \\
\hline Current work & Fixed Bed & 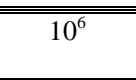 & 230 & 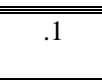 & 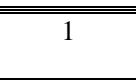 & $\overline{\mathrm{CH}_{4} \text { in } \mathrm{Ar}}$ & $\begin{array}{c}\begin{array}{c}\text { Discussed } \\
\text { below }\end{array} \\
\end{array}$ & $\mathrm{Fe}_{2} \mathrm{O}_{3}$ \\
\hline
\end{tabular}




\section{Test Matrix, Experimental Facility and Test Procedure}

Experiments were conducted according to the $\left(\mathrm{T}, \% \mathrm{CH}_{4}\right)$ test matrix shown graphically in Figure 1 . The matrix produced results at constant temperature and at constant methane feed concentration. These experiments were conducted in NETL's MIR facility, a schematic of which is presented in Figure 2. In the unit, nominally $1.0 \mathrm{~kg}$ of hematite carrier was placed in the bed. Methane and argon or oxygen and argon were fed to the bed during the reduction and oxidizing processes, respectively. Reduction was carried out for either 10 minutes or 5 minutes depending on the test and the oxidation process was carried out for $20 \mathrm{~min}$. The material properties are presented in Table 2.

The test facility consists of the MIR unit which is fed from gas tanks (methane, argon, and oxygen) as shown in Figure 2 through the mass flow controllers which allow precise control of the gases. The MIR unit has an overall height $62.3 \mathrm{~cm}$, an internal diameter of $6.0 \mathrm{~cm}$. It is surrounded by heaters to control the reaction temperature. The feed gas reacts with the hematite inside the vessel and the product gases are directed through a mass spectrophotometer gas analyzer before it exits the system. The reactor temperature is measured at three locations, one just above the distributor plate, one near the top of the bed and one above the bed.

The general experimental facility operation is summarized in Figure 3. In this figure the temperature, gas flow rate and gas species mass fractions are shown. The temperature is ramped up to the operating temperature under an argon gas flow. Once the reactor temperature has stabilized at the set condition (800 ${ }^{\circ} \mathrm{C}$ ), the fuel (reduction) gas flow is initiated and maintained for 10 minutes. This can be seen in Figure 4 by the dip in the argon mass fraction and an increase in the $\mathrm{CO}_{2}$ and $\mathrm{CH}_{4}$ mass fraction values. At this time, the fuel gas is switched off and the argon flow increased to purge the reactor of combustible gas for approximately 25 minutes prior to regenerating the hematite with air. The carrier is regenerated for 20 minutes after which the air flow is stopped and the reactor purged of oxygen prior to starting the next reduction cycle. The temperature for the process is essentially constant at $800{ }^{\circ} \mathrm{C}$ as see by the temperature trace with the exception of a small rise $\left(15^{\circ} \mathrm{C}\right)$ in the gas temperature when air is introduced during regeneration. This temperature rise will be shown to affect the cyclic stability of the carrier in batch operation.

Table 2. Material properties.

$\begin{array}{lrlll}\text { Composition } & & \frac{\text { Units }}{} & & \text { Value } \\ & \mathrm{Fe}_{2} \mathrm{O}_{3} & \% & 95 \\ \text { Inert } & \% & 5 \\ \text { Particle Size } & & \mathrm{um} & 230 \\ \text { Particle Density } & & \mathrm{kg} / \mathrm{m}^{3} & 4770 \\ \text { Langmuir Surface Area } & & \\ & 800{ }^{\circ} \mathrm{C} & \mathrm{m}^{2} / \mathrm{g} & 0.41 \\ & 900{ }^{\circ} \mathrm{C} & \mathrm{m}^{2} / \mathrm{g} & 0.09\end{array}$




\section{Results}

Due to the configuration of the reactor, there is a large recirculation zone located at the top. This can be modeled as a first order decay with a time constant of 40 seconds based upon an argon step change at the flow rates used in the tests. That is, using this time constant, the argon exit trace was converted to a step function, mirroring the input. The exit gas concentrations were corrected using this time constant according to the relation by dividing the measured values by $\left(1-\mathrm{e}^{(-\mathrm{t} / 40)}\right)$ for $\mathrm{t}>0$. The exit gas concentration profiles, corrected for the reactor time constant of the reactor assembly pictured in Figure 2, are shown in Figures 4 to remove diffusion and mixing confounding behavior. The graphs in Figure 4 are placed according to the test matrix (Figure 1). That is, the plots across the top are at a constant concentration ( $8.5 \%$ ) and vary in temperature from $740{ }^{\circ} \mathrm{C}$ on the left to $833^{\circ} \mathrm{C}$ on the right. The plots on the vertical axis are at a constant temperature of $800{ }^{\circ} \mathrm{C}$ and very in $\mathrm{CH}_{4}$ concentration from $5 \%$ at the bottom to $8.5 \%$ at the top.

In general, it can be observed that the curves for the $\mathrm{CO}_{2}$ mass fractions rise rapidly for about the first 50 to 150 seconds - creating a "bubble of $\mathrm{CO}_{2}$ " and then reduce to a gradual decay as the hematite is consumed. The $\mathrm{CO}$ curves have a similar shape - albeit about 20 times lower in magnitude. Breault and Monazam [27] report the " $\mathrm{CO}_{2}$ bubble" observance in other's work and contribute it being the product of a quickly consumed surface reaction. The data at $800{ }^{\circ} \mathrm{C}$ and $8.5 \% \mathrm{CH}_{4}$ deviate from this general shape. More specifically, with all parameters constant the peak $\mathrm{CO}_{2}$ mass fraction is expected to be about 0.01 from the comparison of the $740{ }^{\circ} \mathrm{C}$ and $830{ }^{\circ} \mathrm{C}$ data. The lack of the "bubble" and the maximum of only about 0.06 for the mass fraction require a deeper investigation of the data.

Breault and Monazam [27] report a reduced $\mathrm{CO}_{2}$ peak value and the disappearance in the "bubble" between cycles 1 and 2 for material that was overheated during the first oxidation cycle causing morphological changes to the carrier. Since this behavior is similar, it is possible that the carrier was overheated. This is in fact true as seen in Figure 5 where the first reduction cycle for each test condition is identified by the small circles. The carrier for the $800{ }^{\circ} \mathrm{C}, 8.5 \% \mathrm{CH}_{4}$ test was heated nearly $850{ }^{\circ} \mathrm{C}$ prior to it undergoing the first reduction cycle.

The solids in the $800{ }^{\circ} \mathrm{C}, 8.5 \% \mathrm{CH}_{4}$ test were over heated for a period greater than 20 minutes prior to initiation of the first cycle. High temperature promotes grain growth with loss of what little surface reactant there is for the carrier [28 - 30]. Callister [28] presents a plot showing the general effect of grains growing with time and temperature where grains can grow in diameter by 2 orders of magnitude when heated from $550{ }^{\circ} \mathrm{C}$ to $850{ }^{\circ} \mathrm{C}$ for 10 minutes - times and conditions comparable to this work. Bradshaw and Matas [29] credit this grain growth to decreases in the reduction rate of hematite with CO. Bora et al. [30] show a $30 \%$ increase in grain size when hematite is heated from $800{ }^{\circ} \mathrm{C}$ to $900{ }^{\circ} \mathrm{C}$. In the current work, surface area measurements were taken for the raw material after being held at $800 \mathrm{C}$ and at $900{ }^{\circ} \mathrm{C}$. The surface area at $900{ }^{\circ} \mathrm{C}$ was only $22 \%$ of the surface area at $800{ }^{\circ} \mathrm{C}$. (Table 2). If the loss in surface area is linear with the peak temperature, the material overheated will only have about $70 \%$ of the surface area at $800{ }^{\circ} \mathrm{C}$. This is contrasted with the test at $827^{\circ} \mathrm{C}$, which will have a surface area of about $90 \%$ of that at $800^{\circ} \mathrm{C}$, a level which is well within the experimental controls. The effect of overheating can be seen in the test data presented in Figure 6 for the first and second cycles of the $7.2 \%, 800{ }^{\circ} \mathrm{C}$ test (extracted from [27]). Note the similarity of the cycle 2 curve with that shown in Figure 4 for the $\mathrm{CO}_{2}$ curve at $8.5 \%, 800{ }^{\circ} \mathrm{C}$. In this data (Figure 6), the lack of substantial heat transfer during the fixed bed 
oxidation of the carrier caused overheating by as much as $100{ }^{\circ} \mathrm{C}$ causing a substantial reduction in the carrier's surface area for the second and subsequent cycles [27].

Breault and Monazam [27] noted the importance of only looking at the first cycle of the reduction in determination of the kinetics to other reactor configurations, specifically bubbling fluidized beds where there is sufficient heat transfer to maintain the particle temperature at a low enough level to inhibit grain growth. This importance can be seen by comparing the $\mathrm{CO}_{2}$ production data from a fluidized reduction cycle in a similarly sized reactor (Figure 7) to any of the non-overheated $\mathrm{CO}_{2}$ production data presented in Figure 4. The data in Figure 7 was taken at $850{ }^{\circ} \mathrm{C}$ but since the unit was fluidized, none of the carrier particles were overheated for an extended period of time. And so, the $\mathrm{CO}_{2}$ "bubble" from the surface reaction was maintained without significant degradation as compared to the fixed bed case discussed more thoroughly in this paper. Therefore, the data at $800{ }^{\circ} \mathrm{C}$ and $8.5 \% \mathrm{CH}_{4}$ is omitted from the analysis below.

Another point that needs to be made with respect to developing reactor kinetics is the potential that reduction is not constant across experimental test reactors as has been proposed by Hayes and colleagues [31-34]. At NETL and elsewhere, there has been significant research efforts focused on getting kinetics from the TGA (see Table 1). Hayes et al. [31-34] have looked at the hematite reduction under various chemical potentials that might be seen in different reactors. He has reported that hematite reduces differently depending on the gas phase concentrations above it and that these result in different morphologies for the particles. At NETL, we have seen some morphological changes [27], these were attributed to thermal effects during the oxidation cycle but may also be caused by the mechanism that Hayes et al. presents. The difference between TGA experimental facilities and flow reactor like the MIR are shown in Figure 8. In this figure, the solids inventory volume is plotted against the reactor stoichiometry $\left(\mathrm{g} \mathrm{CH}_{4} / \mathrm{g} \mathrm{Fe}_{2} \mathrm{O}_{3}\right.$ ) where the mass of the gas is the cumulative quantity for the test in the TGA and MIR experiments. As can be seen, the flow reactors and the TGAs are separated by three orders of magnitude with regard to stoichiometry and 6 or more orders of magnitude with respect to reactor volume. According to Hayes [31-34], it is the significantly different stoichiometry (chemical potential) that can lead to different kinetics at the different scales, making it very important to look at the reaction rates of hematite at large scales under similar chemical potentials. Whether or not this holds will be discussed below when activation energies are discussed across the various reactor scales.

\section{Analysis}

Since the hematite is dense with very little surface area or porosity, it is hypothesized that the reaction between the oxygen in the hematite and the $\mathrm{CH}_{4}$ occurs at or very near the surface the surface. Therefore, the weight loss was attributed to occur in a shell surrounding the particle grains. Furthermore, it is assumed that the reaction of the $\mathrm{Fe}_{2} \mathrm{O}_{3}$ and the $\mathrm{CH}_{4}$ utilizes most of the oxygen at the grain surface. Conceptually, this is shown in Figure 9. In this figure, a slice of a small section of the particle surface is shown consisting of 3 unit cells (note fine dashed line surrounding unit cell [35]) in length and 2 deep (into particle/grain). In the sketch on the left, the surface (left edge) is fully oxidized. In the right side of the sketch, the same section of the particle is shown partially reduced to $\mathrm{FeO}$ at the surface (left edge). According to Chatterjee [36], the reduction of dense iron ore occurs by oxygen diffusing to the surface by a lattice vacancy mechanism. 
Based upon the earlier work of Breault and Monazam [27], the reaction of methane with hematite takes place according to the process defined below. Methane migrates to the particle surface region (outer shell of particles/grains) and reacts within a shallow layer on the order of $70^{\circ} \mathrm{A}$ associated with the shell to produce carbon monoxide and hydrogen gaseous species and likely solids species FeO. This is shown in the sketch presented in Figure 10. The carbon monoxide either reacts very rapidly with hematite in in this shell or escapes the particle though the large pores to react downstream. The hydrogen undergoes the same process. Reported literature [37-38] reaction kinetics for hematite and hydrogen are so fast that the observed free hydrogen as noted above in the results section are at the detection limit except when the methane undergoes cracking late into the particle reduction stage. Once a reasonable large share of the surface available oxygen has been consumed, oxygen diffuses from the core (particle/grain) to the surface region where it reacts with the migrating methane in the same chemical reactions although the rate is controlled by the speed at which oxygen can diffuse from the core hematite lattice to the attached methane. Therefore, the following reactions are proposed

$$
\begin{aligned}
& \mathrm{CH}_{4}+\mathrm{Fe}_{2} \mathrm{O}_{3} \|_{\mathrm{s}} \rightarrow \mathrm{CO}+2 \mathrm{H}_{2}+2 \mathrm{FeO} \\
& \mathrm{CH}_{4}+\mathrm{Fe}_{2} \mathrm{O}_{3} \|_{\mathrm{c}} \rightarrow \mathrm{CO}+2 \mathrm{H}_{2}+2 \mathrm{FeO} \\
& \mathrm{CO}+\mathrm{Fe}_{2} \mathrm{O}_{3} \|_{\mathrm{s}} \rightarrow \mathrm{CO}_{2}+2 \mathrm{FeO} \\
& \mathrm{CO}+\mathrm{Fe}_{2} \mathrm{O}_{3} \|_{\mathrm{c}} \rightarrow \mathrm{CO}_{2}+2 \mathrm{FeO} \\
& \mathrm{H}_{2}+\mathrm{Fe}_{2} \mathrm{O}_{3} \|_{\mathrm{s}} \rightarrow \mathrm{H}_{2} \mathrm{O}+2 \mathrm{FeO} \\
& \mathrm{H}_{2}+\mathrm{Fe}_{2} \mathrm{O}_{3} \|_{\mathrm{c}} \rightarrow \mathrm{H}_{2} \mathrm{O}+2 \mathrm{FeO}
\end{aligned}
$$

Since no $\mathrm{H}_{2}$ was measured, its rate of reaction is not explored. Therefore, the reaction rates for the Equations 10-13 are given below in Equations 16 to 19.

$$
\begin{aligned}
& R_{1, \mathrm{CH}_{4}}=R_{1, \mathrm{Fe}_{2} \mathrm{O}_{3} \|_{S}}=-R_{1, \mathrm{CO}}=-\frac{R_{1, \mathrm{H}_{2}}}{2}=-\frac{R_{1, \mathrm{FeO}}}{2} \\
& R_{2, \mathrm{CH}}=R_{2, \mathrm{Fe}_{2} \mathrm{O}_{3} \|_{\mathrm{C}}}=-R_{2, \mathrm{CO}}=-\frac{R_{2, \mathrm{H}}}{2}=-\frac{R_{2, \mathrm{FeO}}}{2} \\
& R_{3, \mathrm{CO}}=R_{3, \mathrm{Fe}_{2} \mathrm{O}_{3} \|_{S}}=-R_{3, \mathrm{CO}}=-\frac{R_{3, \mathrm{FeO}}}{2} \\
& R_{4, \mathrm{CO}}=R_{4, \mathrm{Fe}_{2} \mathrm{O}_{3} \|_{\mathrm{C}}}=-R_{4, \mathrm{CO}_{2}}=-\frac{R_{4, \mathrm{FeO}}}{2}
\end{aligned}
$$

The overall rate of reaction for $\mathrm{CH} 4, \mathrm{CO} 2$ and $\mathrm{CO}$ is given by Equations 20 through 22.

$$
\begin{aligned}
& R_{\mathrm{CH}_{4}}=R_{1, \mathrm{CH}_{4}}+R_{2, \mathrm{CH}_{4}} \\
& R_{\mathrm{CO}_{2}}=R_{3, \mathrm{CO}_{2}}+R_{4, \mathrm{CO}_{2}}
\end{aligned}
$$



model and the closed form solution for a parallel process as identified by Monazam et al. [24, 37, 40].

$$
R_{\mathrm{CH}_{4}}=\frac{d\left(m^{\prime}{ }_{C H_{4}}(t)\right)}{d t}
$$

The closed form solution for methane going to products in parallel paths is presented in the following equation.

$$
m^{\prime}{ }_{C H_{4}(t)}=w_{\text {sur }}\left(1-e^{-a_{\text {sur }} t^{n_{\text {sur }}}}\right)+w_{\text {cor }}\left(1-e^{-a_{\text {cor }} t^{n_{\text {cor }}}}\right)
$$

Where $m_{C H_{4}(t)}$ is the mass of methane leaving the reactor at time, $t$, and $m_{C H_{4}(0)}^{\prime}$ is the mass of methane entering the reactor. The relative weights of the two reactions are $w_{\text {sur }}$ and $w_{\text {cor }}$, where

$$
\frac{w_{s u r}+w_{c o r}}{m_{C H_{4}(0)}^{\prime}}=1
$$

The nucleation rate constants for the two reactions are $a_{s u r}$ and $a_{c o r}$ and the corresponding nucleation shape parameters are $n_{\text {sur }}$ and $n_{\text {cor }}$.

The above equation was fitted to the data for the experiments with the fit parameter, $\mathrm{R}^{2}$, ranging from 0.99 to 0.999 . An example plot is shown in Figure 11 for the test condition $\mathrm{T}=800^{\circ} \mathrm{C}$ and $X_{C H 4}$, in $=7.23 \%$. The $\mathrm{R}^{2}$ value for this example is 0.999 and the absolute average percent deviation (AAPD) is $0.001 \%$. The results for the relative reaction weights, the nucleation rate constants and the nucleation shape factors are presented in Table 3.

Table 3. $\mathrm{CH}_{4}$ Model Parameter Fit Values

$\begin{array}{lcccc}\mathrm{T},{ }^{\circ} \mathrm{C} & 750 & 825 & 800 & 800 \\ \mathrm{CH}_{4}, \% & 8.59 & 8.63 & 5.05 & 7.24 \\ w_{\text {cor }, C H} & 0.00097 & 0.00127 & 0.00261 & 0.00139 \\ w_{\text {sur }, C H_{4}} & 0.000725 & 0.00043 & 0.00052 & 0.00055 \\ n_{\text {cor }, C H_{4}} & 1.41 & 1.00 & 0.55 & 0.64 \\ n_{\text {sur }, C H_{4}} & 2.47 & 1.90 & 1.75 & 1.77 \\ a_{\text {cor }, C H_{4}}, \mathrm{~g} / \mathrm{s} & 1.69 \mathrm{E}-04 & 2.52 \mathrm{E}-03 & 2.25 \mathrm{E}-02 & 1.22 \mathrm{E}-02 \\ a_{\text {sur }, C H_{4}}, \mathrm{~g} / \mathrm{s} & 3.22 \mathrm{E}-06 & 9.99 \mathrm{E}-05 & 5.33 \mathrm{E}-04 & 1.86 \mathrm{E}-04\end{array}$

The results from the fit analysis show that the average value of $n_{s u r, \mathrm{CH}_{4}}$ is equal to 2 and $n_{c o r, C H_{4}}$ is equal to 1 for all cases as was obtained by Monazam et al for the TGA [20]. The functionality is show below. This average value of $n_{\mathrm{cor}, \mathrm{CH}_{4}}$ equal to 1 is the result that most often shows up in reviewed literature. The early time results are neglected and then bulk of the long reduction time data fits a conventional Arrhenius rate expression quite well. The problem with that analysis is that the conversion predictions are 

the conversion by $50 \%$ for times on the order of $5 \mathrm{~min}$ as the conversion associated with the nucleation in the grain shell counts for a significant part of the conversion.

The functionality of $w_{\mathrm{Cor}, \mathrm{CH}}, n_{\mathrm{sur}, \mathrm{CH}_{4}}, n_{\mathrm{cor}, \mathrm{CH}_{4}}, a_{\mathrm{sur}, \mathrm{CH}_{4}}$, and $a_{\mathrm{cor}, \mathrm{CH}}$ are provided below with respect to temperature and inlet concentration (mass fraction). The average $\mathrm{R}^{2}$ for the five curve fits was 0.953 for the expressions below:

$$
\begin{array}{ll}
w_{\text {cor }, C H_{4}}=4.224 \times 10^{4} \times T\left({ }^{\circ} \mathrm{C}\right)^{-2} \times X_{C H_{4}}^{-2} & \left(\mathrm{R}^{2}=96.4 \%\right) \\
n_{\text {cor }, C H_{4}}=1.041 \times 10^{4} \times T\left({ }^{\circ} \mathrm{C}\right)^{-2} \times X_{C H_{4}}^{2} & \left(\mathrm{R}^{2}=90.0 \%\right) \\
n_{\text {sur }, C H_{4}}=5.034 \times 10^{8} \times T\left({ }^{\circ} \mathrm{C}\right)^{-3} \times X_{C H_{4}}^{0.33} & \left(\mathrm{R}^{2}=95.6 \%\right) \\
a_{\text {sur }, \mathrm{CH} H_{4}}^{\left(\frac{1}{n_{\text {sur } C H_{4}}}\right)}=A X_{C H_{4}}^{n} e^{-E / R T}=7.443 X(\%)_{C H_{4}}^{1} e^{-5124 / T} & \left(\mathrm{R}^{2}=95.1 \%\right) \\
a_{\text {cor, }, H_{4}}^{\left(\frac{1}{n_{\text {cor } C H_{4}}}\right)}=A X_{C H_{4}}^{n} e^{-E / R T}=0.059 X(\%)_{C H_{4}}^{2} e^{-8100}\left(\frac{300}{t_{R}}\right) \cdot 7 & \left(\mathrm{R}^{2}=99.4 \%\right)
\end{array}
$$

The corresponding Activation energy is $41.7 \mathrm{~kJ} / \mathrm{mol}$ and $65.9 \mathrm{~kJ} / \mathrm{mol}$ for the surface and core, respectively. This corresponds to $36.3 \mathrm{~kJ} / \mathrm{mol}$ and $34.4 \mathrm{~kJ} / \mathrm{mol}$ obtained by Monazam et al. [20] in their analysis of TGA data for the same temperature range.

Looking next at the $\mathrm{CO}_{2}$ production (see Figures 4), it can be see that the $\mathrm{CO}_{2}$ first rises rapidly - the likely product of the $\mathrm{CO}$ produced from reaction 1 reacting in reaction 3 . Since the production of $\mathrm{CO}_{2}$ is dependent upon the solid reaction present, equation (methane breakthrough) needs to be modified to account for the disappearance of the solid reactant. The solid species present at any time is proportional to $\left(e^{-a_{\text {surt }} n_{\text {sur }}}\right)_{\mathrm{CH}_{4}}$ and $\left(e^{-a_{\text {cor }} t^{n_{\text {cor }}}}\right)_{\mathrm{CH}_{4}}$ for the surface and core species, respectively. Therefore, including these terms in the expression for the $\mathrm{CO}_{2}$ reactor exit gas gives

$$
\begin{aligned}
& R_{\mathrm{CO}_{2}}=\frac{d\left(m^{\prime}{ } \mathrm{O}_{2}(t)\right)}{d t}
\end{aligned}
$$

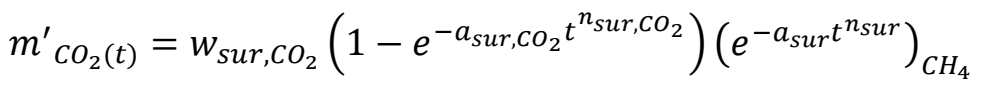

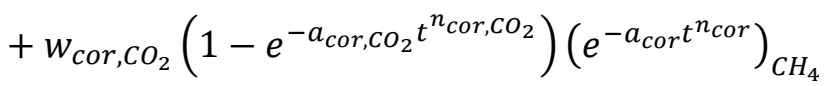


Table 4. $\mathrm{CO}_{2}$ Model Parameter Fit Values

$\begin{array}{lrrrr}\mathrm{T},{ }^{\circ} \mathrm{C} & 750 & 825 & 800 & 800 \\ \mathrm{CH}_{4}, \% & 8.59 & 8.63 & 5 & 7.23 \\ w_{\text {sur }, \mathrm{CO}_{2}} & 0.00490 & 0.00431 & 0.00485 & 0.00217 \\ w_{\text {cor }, \mathrm{CO}_{2}} & 0.01266 & 0.01149 & 0.00561 & 0.00358 \\ n_{\text {sur }, \mathrm{CO}_{2}} & 1.56791 & 1.29299 & 1.53959 & 1.58423 \\ n_{\text {cor }, \mathrm{CO}_{2}} & 0.75465 & 0.78760 & 0.72912 & 0.71209 \\ a_{\text {sur }, \mathrm{CO}_{2}}, \mathrm{~g} / \mathrm{s} & 0.00359 & 0.00481 & 0.00447 & 0.00195 \\ a_{\text {cor }, \mathrm{CO}_{2}}, \mathrm{~g} / \mathrm{s} & 0.00553 & 0.01699 & 0.11444 & 0.05825\end{array}$

The results for the example $\left(\mathrm{T}=800^{\circ} \mathrm{C}\right.$ and $\left.X_{C H 4, \text { in }}=7.23 \%\right)$, are presented in Figure 12. The combined surface and core models give an $\mathrm{R}^{2}$ value greater than 99.5 for this example and greater than 99.4 for all the test points.

The functionality of $w_{\mathrm{Sur} \mathrm{CO}_{2}}, w_{\mathrm{cor}, \mathrm{CO}_{2}}, n_{\mathrm{sur}, \mathrm{CO}_{2}}, n_{\mathrm{cor}, \mathrm{CO}_{2}}, a_{\mathrm{sur}, \mathrm{CO}_{2}}$, and $a_{\mathrm{cor}, \mathrm{CO}_{2}}$ are provided below with respect to temperature and inlet concentration (mass fraction). The average $\mathrm{R}^{2}$ for the four fits was 0.935 for the expressions below:

$$
\begin{aligned}
& w_{\text {sur }, \mathrm{CO}_{2}}=1.01 \times 10^{10} \times T\left({ }^{\circ} \mathrm{C}\right)^{-4} \times X_{C H_{4}}^{-1} \times\left(\frac{300}{t_{R}}\right) \\
& w_{c o r, \mathrm{CO}_{2}}=0.371 \times T\left({ }^{\circ} \mathrm{C}\right)^{-1} \times X_{\mathrm{CH}_{4}}^{1.5} \times\left(\frac{300}{t_{R}}\right)^{1.5} \\
& n_{\text {sur }, \mathrm{CO}_{2}}=53081 \times T\left({ }^{\circ} \mathrm{C}\right)^{-1.5} \times X_{\mathrm{CH}_{4}}^{-0.25} \times\left(\frac{300}{t_{R}}\right)^{-0.15} \\
& n_{\text {cor }, \mathrm{CO}_{2}}=0.7459 \\
& a_{\text {sur }, \mathrm{CO}_{2}}^{\left(\frac{1}{n_{\text {sur } C O_{2}}}\right)}=A X_{C H_{4}}^{n} e^{-E / R T}=0.1798\left(X(\%)_{C H_{4}}{ }^{-0.5}\right)\left(\frac{300}{t_{R}}\right)^{0.25} e^{-1100 / T} \\
& a_{\text {cor }, \mathrm{CO}_{2}}^{\left(\frac{1}{n_{\mathrm{Cr}, \mathrm{CO}_{2}}}\right)}=A X_{C H_{4}}^{n} e^{-E / R T}=6.61 \times 10^{11} \times\left(X(\%)_{C_{4}}{ }^{-4}\right)\left(\frac{300}{t_{R}}\right)^{-1} e^{-25509 / T}
\end{aligned}
$$

This provides an activation energy of $9.0 \mathrm{~kJ} / \mathrm{mol}$ for the surface reaction and is comparable to that found by Monazam et al. [40] in their analysis of TGA data of $19 \mathrm{~kJ} / \mathrm{mol}$. The functionality for the core is shown in Equation (38). It gives an activation energy of $208.7 \mathrm{~kJ} / \mathrm{mol}$. This level is significantly greater than that found by Monazam et al. [40]. It is however consistent with the activation energy levels associated for oxygen vacancy diffusion in hematite (154 to 203 [41] and 160 [42]. It is also consistent with the value of $184 \mathrm{~kJ} / \mathrm{mol}$ obtained for iron ore by Lou et al. [23].

The applicability of the rates presented here can be evaluated by comparing the post-fit predictions for the exit $\mathrm{CH}_{4}$ and $\mathrm{CO}_{2}$ data for each case and comparing those values with the experimental data to evaluate the error in the predictions. Equations 25 through 30 were used to develop kinetic parameters for the methane conversion. These values were then used to calculate the exiting methane flow rate as a function 
of time from Equation 24. The results of the model are shown in Figure 13 and 14. Figure 13 presents an example model prediction curve for the $\mathrm{CH}_{4}$ leaving the reactor and compares that to the data for the same case (Case $5,800{ }^{\circ} \mathrm{C}, 7.23 \% \mathrm{CH}_{4}$ ). The $\mathrm{R}^{2}$ value between the model and the data for this case is $99.5 \%$. The $\mathrm{R}^{2}$ for all the test cases ranged for from 98.7 to $99.9 \%$. Figure 14 presents the reacted methane for all the cases and compares it to the model predictions. The error ranged from $1 \%$ to $9 \%$ with the average being $5.1 \%$ excluding Case 3 .

A comparison between the model (Equations 33 through 38) and the data is presented in Figures 15 and 16. Figure 15 provides an illustration of the typical fit between the data and the model with the $\mathrm{R}^{2}$ for this case being $97.8 \%$ The $\mathrm{R}^{2}$ for all the cases (excluding Case 3 ) ranged from $92 \%$ to $98 \%$. Figure 15 presents the $\mathrm{CO}_{2}$ produced for all the cases. The average error is $8.0 \%$ with the range being 1 to $12 \%$, excluding Case 3.

\section{Conclusion}

Methane combustion using hematite as the oxygen carrier was investigated in a fixed bed reactor with application for chemical looping combustion process. Hematite is identified as an important potential oxygen carrier and has emerged as one of the candidates for use as oxygen carrier for CLC and is analyzed in this paper work as it is a relatively in expensive carrier. During this study, the hematite did not agglomerate. It maintained reasonable reactivity and demonstrated durability through multiple cycles even though it was over heated during the oxidation portion of the cycle which caused some of the reduction in its reactivity due to morphological changes (grain growth and subsequent surface area reduction).

The obtained conversion data in the reduction condition can be represented by a two-step process for the reaction of the ore with methane to form $\mathrm{CO}$ and $\mathrm{H}_{2}$ and then the reaction of the $\mathrm{CO}$ to form $\mathrm{CO}_{2}$. The hydrogen was at the detection limit of the analyzer and was assumed to convert completely and instantly to $\mathrm{H}_{2} \mathrm{O}$. The surface reaction have activation energies of $41.7 \mathrm{~kJ} / \mathrm{mol}$ for the $\mathrm{CH}_{4}$ reaction and $9.0 \mathrm{~kJ} / \mathrm{mol}$ for $\mathrm{CO}_{2}$ formation reaction which are both comparable to those found by Monazam et al. [20, 40]. The activation energies for the two reactions involving core oxygen are much higher; $65.9 \mathrm{~kJ} / \mathrm{mol}$ for the $\mathrm{CH}_{4}$ reaction and $208.7 \mathrm{~kJ} / \mathrm{mol}$ for the $\mathrm{CO}_{2}$ formation reaction. These values are comparable to those associated with oxygen vacancy diffusion [41,42], especially the latter for $\mathrm{CO}_{2}$ formation. Additionally, it is found that $\mathrm{CO}$ emissions from the fuel reactor are very small and that $\mathrm{H}_{2}$ produced by partial oxidation of $\mathrm{CH}_{4}$ contributes to the reduction of the bed material.

\section{Acknowledgements}

The authors acknowledge the Department of Energy for funding the research through the office of Fossil Energy's Gasification Technology and Advanced Research funding programs. Special thanks go to Duane Miller and Rich Eddy of URS Energy \& Construction, Inc. for their assistance with experimental work and data collection and to Dave Huckaby and Justin Weber for their insight on the kinetic discussion. 


\section{Disclaimer}

The U.S. Department of Energy, NETL and REM contributions to this report was prepared as an account of work sponsored by an agency of the United States Government. Neither the United States Government nor any agency thereof, nor any of their employees, makes any warranty, express or implied, or assumes any legal liability or responsibility for the accuracy, completeness, or usefulness of any information, apparatus, product, or process disclosed, or represents that its use would not infringe privately owned rights. Reference herein to any specific commercial product, process, or service by trade name, trademark, manufacturer, or otherwise does not necessarily constitute or imply its endorsement, recommendation, or favoring by the United States Government or any agency thereof. The views and opinions of authors expressed herein do not necessarily state or reflect those of the United States Government or any agency thereof.

The authors declare no competing financial interest.

\section{References}

1. J. Ciferno, J. Litynski, L. Brickett, J. Murphy, R. Munson, C. Zaremsky, J. Marano, J. Strock, 2011, DOE/NETL Advanced CO2 Capture R\&D Program: Technology Update, U.S Department of Energy.

2. T. F. Wall, 2007, Combustion processes for carbon capture, Proceedings of the Combustion Institute 31, 31-47.

3. L. S. Fan, 2010, Chemical Looping Systems for Fossil Energy Conversion, John Wiley and Sons, NJ,

4. P. Cho, T. Mattisson, A. Lyngfelt, 2005, Carbon formation on nickel and iron oxide containing oxygen carriers for chemical-looping combustion. Ind. Eng. Chem. Res., 44, 668-676.

5. T. Mattisson, A. Lyngfelt, P. Cho, 2000, Possibility of using iron oxide as an oxygen carrier for combustion of methane with removal of $\mathrm{CO} 2$ - Application of chemical looping combustion, Fifth International Conference on Greenhouse Gas Control Technologies, Cairns, Australia, , 205-210.

6. S. R. Son, S. D. Kim, 2006, Chemical Looping Combustion with $\mathrm{NiO}$ and $\mathrm{Fe} 2 \mathrm{O} 3$ in a Thermobalance and Circulating Fluidized Bed Reactor with Double Loop", Ind. Eng. Chem. Res., 45, 2689-2696.

7. A. Abad, J. Adanez, F. Garcia-Labiano, L. F. de Diego, P. Gayan, J. Celaya, 2007 , Mapping of range of operational conditions for $\mathrm{Cu}-, \mathrm{Fe}-$, and Ni-based oxygen carriers in chemical looping combustion, CES, 62, 533-549

8. A. Abad, T. Mattisson, A. Lyngfelt, M. Johansson, 2007, The use of iron as oxygen carrier in a chemical-looping reactor, Fuel 86, 1021-1035

9. A. Abad, J. Adanez, A. Cuadrat, F. Garcia-Labiano, P. Gayan, L. F. de Diego, 2011, Kinetics of redox reactions of ilmentite for chemical looping combustion, CES, 66, 689-702

10. J. Adanez, F. Garcia-Labiano, L. F. de Diego, P. Gayan, J. Celaya, A. Abad, 2005, Characteristics of oxygen carriers for chemical-looping combustion, Greenhouse Gas Control Technologies, Vol. 1, ed.: E.S. Rubin, D. W. Keith and C.F. Gilboy, Elservier Ltd.

11. P. Cho, T. Mattissson, A. Lyngfelt, 2002 , Reactivity of iron oxide with methane in a laboratory fluidized bed - application of chemical looping combustion, Proceedings of the 7th International Conference on Circulating Fluidized Beds (CFB-7), Niagara Falls, Ontario, May 5-8, 2002; pp 599-606

12. P. Gayan, M. A. Pans, M. Ortiz, A. Abad, L. F. de Diego, J. Garcia-Labiano, J. Adanez, 2012, Testing of highly reactive impregnated $\mathrm{Fe} 2 \mathrm{O} 3 / \mathrm{Al} 2 \mathrm{O} 3$ oxygen carrier for a SR-CLC system in a continuous CLC unit, Fuel Processing Technology 96, 37-47 
13. K. S. Go, S. R. Son, S. D. Kim, 2008, Reaction kinetics of reduction and oxidation of metal oxides for hydrogen production, IJHE 33, 5986-5995

14. F. He., H. Wang, Y. Dai, 2007, Application of Fe2O3/A12O3 composite particles as oxygen carrier of chemical looping combustion, Jour. Natural Gas Chemistry 16, 155-161

15. M. Johansson, T. Mattisson, A. Lyngfelt, 2004, Investigation of Fe2O3 with MgAl2O4 for chemicallooping combustion”, Ind. Eng. Chem. Res. 43, 6978-6987

16. H. Leion, A. Lyngfelt, M. Johansson, E. Jerndal, T. Mattisson, 2008, The use of ilmenite as an oxygen carrier in chemical-looping combustion, Chem. Eng. Res and Des., 86, 1017-1026

17. T. Mattisson, M. Johansson, A. Lyngfelt, 2004, Multicycle reduction and oxidation of different types of iron oxide particles- Application to chemical-looping combustion, Energy Fuels, 18, 628-637.

18. T. Mendiara, A. Abad, , L. F. de Diego, J. Garcia-Labiano, P. Gayan, J. Adanez, 2012, Use of an Febased residual from alumina production as an oxygen carrier in chemical-looping combustion, Energy Fuels, 26, 1420-1431

19. B. Moghtaderi, H. Song, 2010, Reduction of Properties of Physically mixed metallic oxide oxygen carriers in chemical looping combustion, Energy Fuels, 24, 5359-5368

20. E. R. Monazam, R. W. Breault, R. Siriwardane, G. Richards, S. Carpenter, 2013, Kinetics of the reduction of hematite ( $\mathrm{Fe} 2 \mathrm{O} 3)$ by methane $(\mathrm{CH} 4)$ during chemical looping combustion: A global mechanism, Chemical Engineering Journal, Volume 232, October Pages 478-487

21. S. R. Son, S. D., Kim, 2005, Chemical-looping combustion with inherent CO2 separation in annual circulating fluidized bed reactor, Proceedings $9^{\text {th }}$ International Conference on Environmental Science and Technology, B-871 - B-876

22. J. Zhang, Q. Gou, Y. Liu, and Y. Cheng, 2012, Preparation and characterization of Fe2O3/Al2O3 using the solution combustion approach for chemical looping combustion, Ind. Eng. Chem. Res. 51, 12773-12781

23. M. Lou, S. Wang, L. Wang, and M. Lv, 2014, Reduction kinetics of iron-based oxygen carriers using methane for chemical looping combustion, JPS 270, 434-440

24. Y. Zhang, E. Doroodchi, B. Moghtaderi, "Chemical looping combustion of ultra low concentration of methane with $\mathrm{Fe}_{2} \mathrm{O}_{3} / \mathrm{Al}_{2} \mathrm{O}_{3}$ and $\mathrm{CuO} / \mathrm{SiO}_{2}$ ", Applied Energy 113, 1916-1923

25. H. R. Forutan, E. Karimi, A. Hafizi, M. R. Rahampour, P. Keshavarz, 2014, Expert representation chemical looping reforming: A comparative study of $\mathrm{Fe}, \mathrm{Mn}, \mathrm{Co}$ and $\mathrm{Cu}$ as oxygen carriers supported on $\mathrm{AL}_{2} \mathrm{O}_{3}$, JIEC, Volume 21, 25 January 2015, Pages 900-911

26. Y. Ku, H-C. Wu, P-C. Chiu, Y-H. Tseng, Y-L. Kou, Methane combustion by moving bed fuel reactor with $\mathrm{Fe}_{2} \mathrm{O}_{3} / \mathrm{Al}_{2} \mathrm{O}_{3}$ oxygen carriers, Applied Energy 113, 1909-1915

27. R. W. Breault, E. R. Monazam, 2014, Fixed bed reduction of hematite under alternating reduction and oxidation cycles, Applied Energy 145 (2015) 180-190

28. W. D. Callister, Jr., 2000, Materials Science and Engineering Applications, John Wiley and Sons, New York.

29. A. V. Bradshaw, A. G. Matas, 1976, Structual changes and kinetics in the gaseous reduction of hematite, Metallurgical Tranactions B, Vol 7B, 81-87

30. D. K. Bora, A. Braun, S. Erat, O. Safonova, T. Graule, and E. C. Constable, 2012, Evolution of structural properties of iron oxide nano particles during temperature treatment from $250{ }^{\circ} \mathrm{C}-900{ }^{\circ} \mathrm{C}$ : $\mathrm{X}$-ray diffraction and Fe K-shell pre-edge X-ray absorption study, Current Applied Physics Volume 12, Issue 3, Pages 817-825

31. P. C. Hayes, P. Grieveson, 1981, The effects of nuclueation and growth on the reduiction of $\mathrm{Fe} 2 \mathrm{O} 3$ to Fe3O4, Metallurgical Tranactions B, Vol 12B, 319-326

32. P. C Hayes, P. Grieveson, 1981, Microstructual changes on the reduction of hematite to magnetite, Metallurgical Tranactions B, Vol 12B, 579-587

33. P. Baguley, D. H. St. John, P. C. Hayes, 1983, The conditions for the formation of lath and porous magnetite on reduction of hematite in $\mathrm{H} 2 / \mathrm{H} 2 \mathrm{O}$ gas mixtures, Metallurgical Tranactions B, Vol 14B, 513-514 
34. S.P. Matthew, P. C. Hayes, 1990, Microstructtual changes occurring during the gaseous reduction of magnetite, Metallurgical Tranactions B, Vol 21B, 153-172

35 . Semiconductors Vol. III: Non-Tetrahedrally Bonded Binary Compounds II, Ed. O. Madelung, Springer-Verlag Berlin Heidelberg New York, 41d

36. A. Chatterjee, 1994, Beyond the Blast Furnace, CRC Press, 2-18.

37. E. R. Monazam, R. W. Breault, and R. Siriwardane, 2014, Kinetics of Hematite to Wüstite by Hydrogen for Chemical Looping Combustion, Energy Fuels, 28 (8), pp 5406-5414

38. A. Pineau, N. Kanari, I. Gaballah, 2006, Kinetics of reduction of iron oxides by H2: Part I: Low temperature reduction of hematite, Thermochimica Acta 447, 89-100

39. J-M. Pang, P-R. Guo, P. Zhao, C-Z.; Cao, D-w. Zhang, 2009, Influence of Size of Hematite Powder on Its Reduction Kinetics by $\mathrm{H} 2$ at Low Temperature, J. of Iron and Steel Res. Int. 16 (5), 07-11.

40 E. R. Monazam, R. W. Breault, and R. Siriwardane, 2014, Reduction of hematite (Fe2O3) to wüstite $(\mathrm{FeO})$ by carbon monoxide $(\mathrm{CO})$ for chemical looping combustion, Chemical Engineering Journal 242, 204-210

41. A. Atkinson, 1986, Diffusion in Oxides of the First Transition Series Metals, Atomic Energy Research Establishment Harwell (England), ADA190091.

42. O. Warschkow, D. E. Ellis, J. Hwang, N. Mansourian-Hadavi, and T. O. Mason, 2002, Defects and charge transport near the hematite (0001) surface: An atomic study of oxygen vacancies, J Am.

Ceram. Soc., 85 [1]213-220 


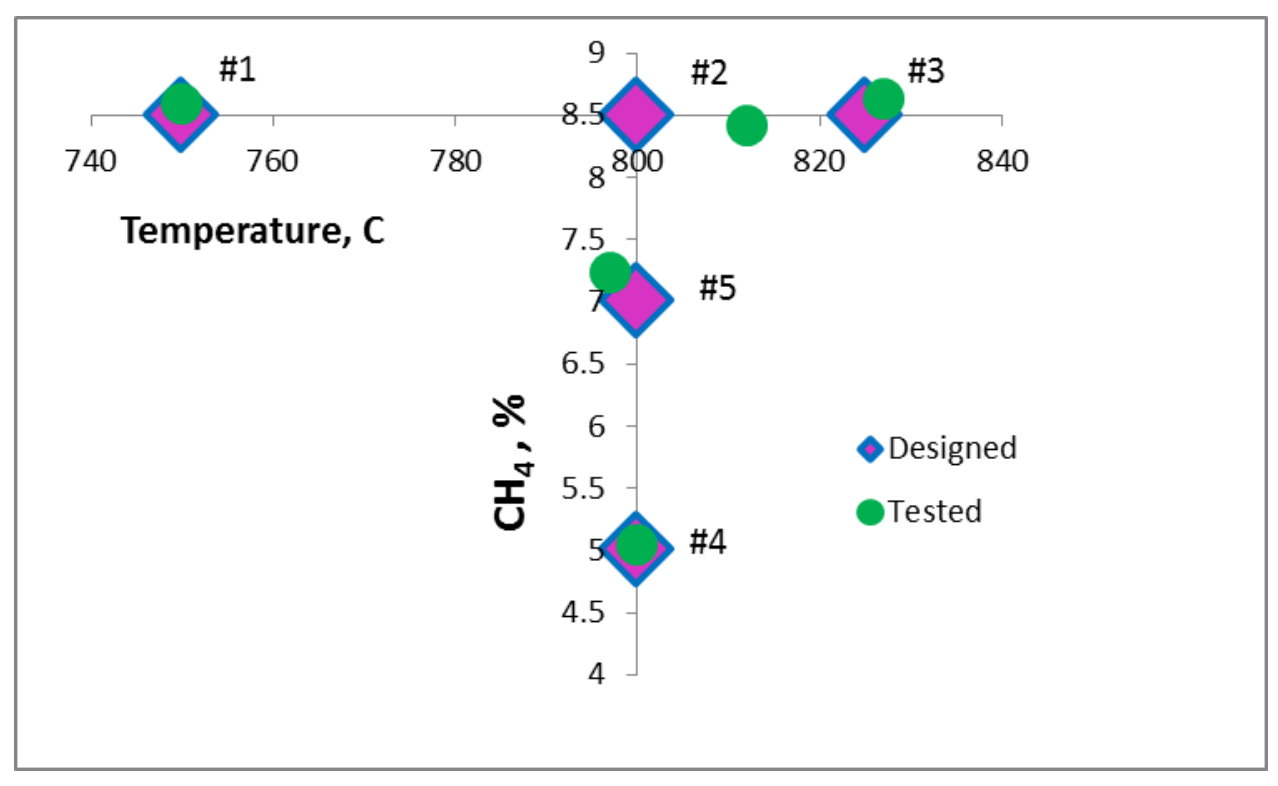

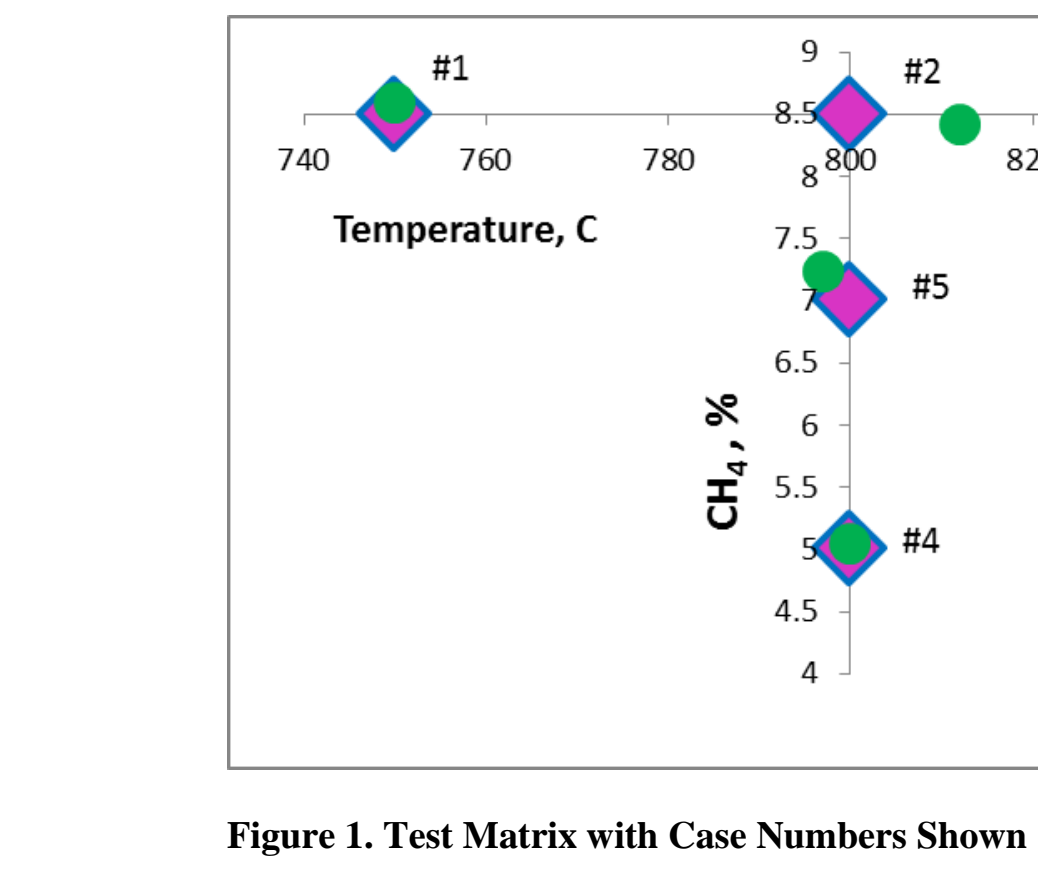

Figure

(1)

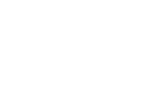

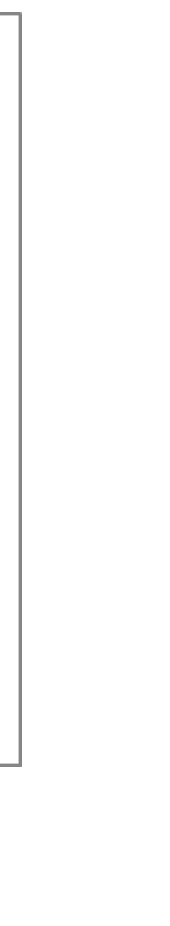

(a)

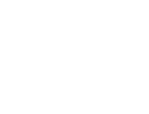
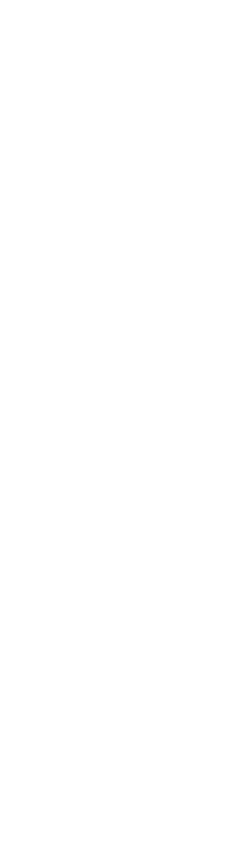


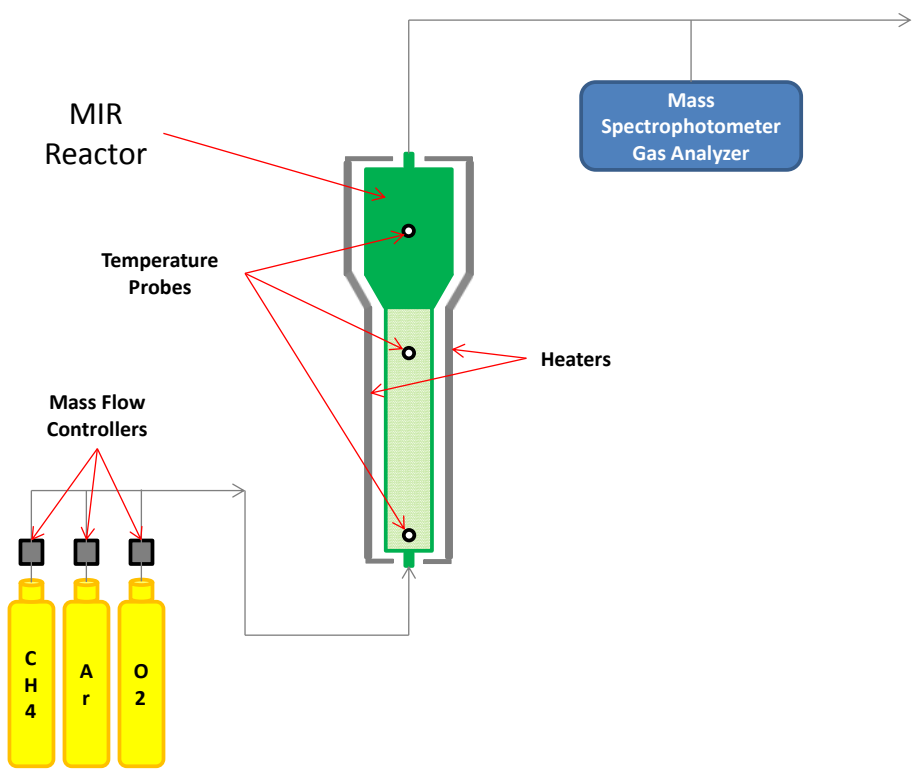

Figure 2. Experimental Test Facility 


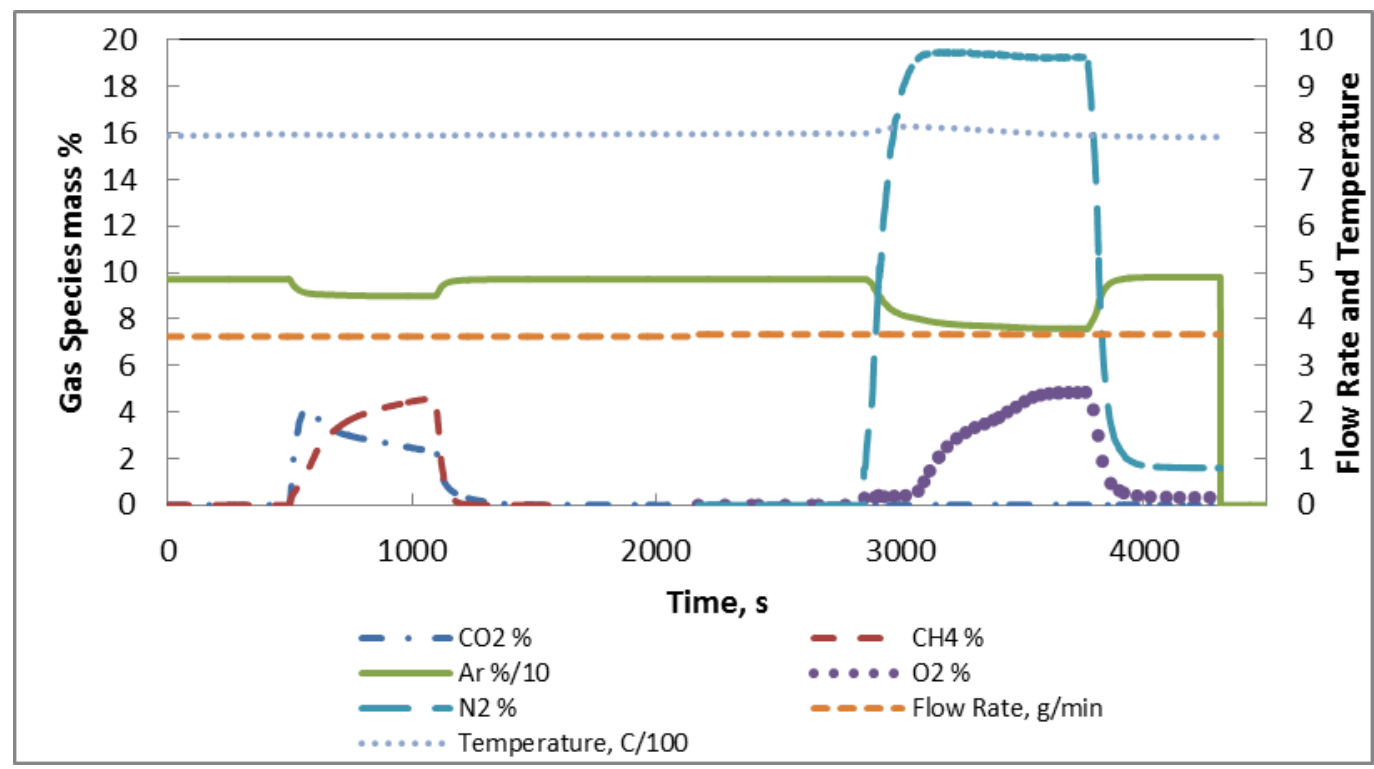

Figure 3. Typical operating cycle for experiments 

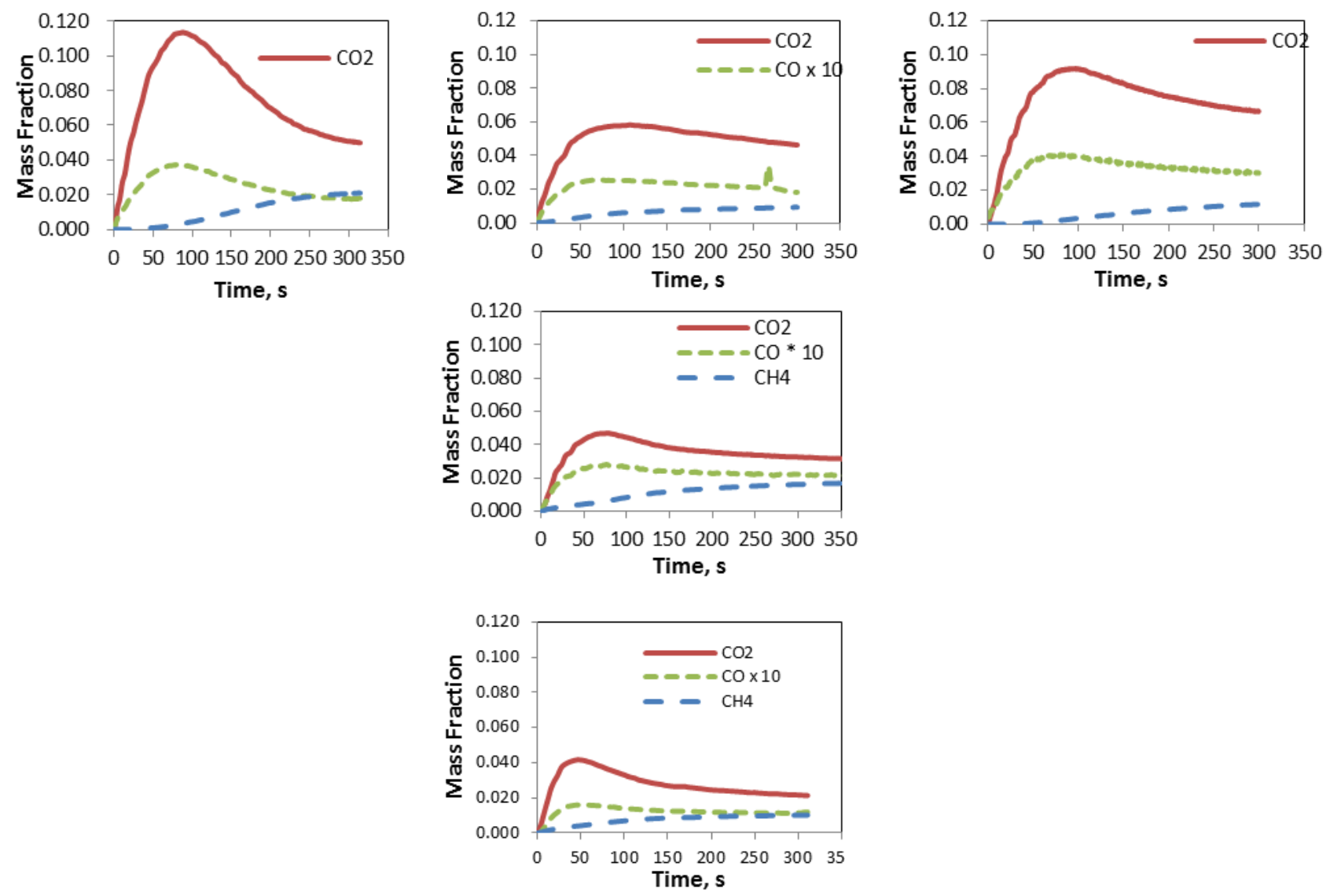

Figure 4 Test Results 


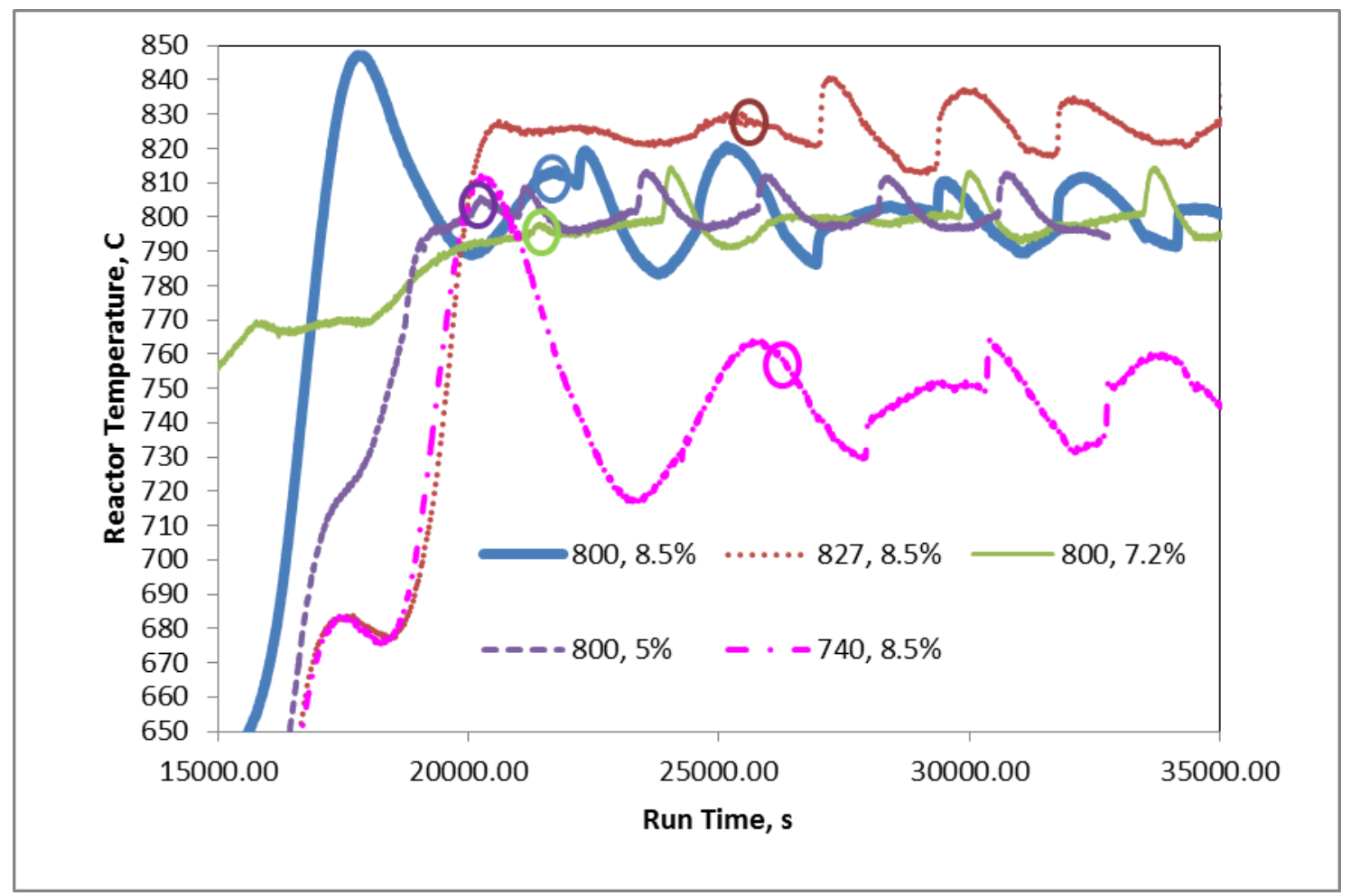

Figure 5. Temperature conditions leading to cycle 1 test - denoted with circle. 


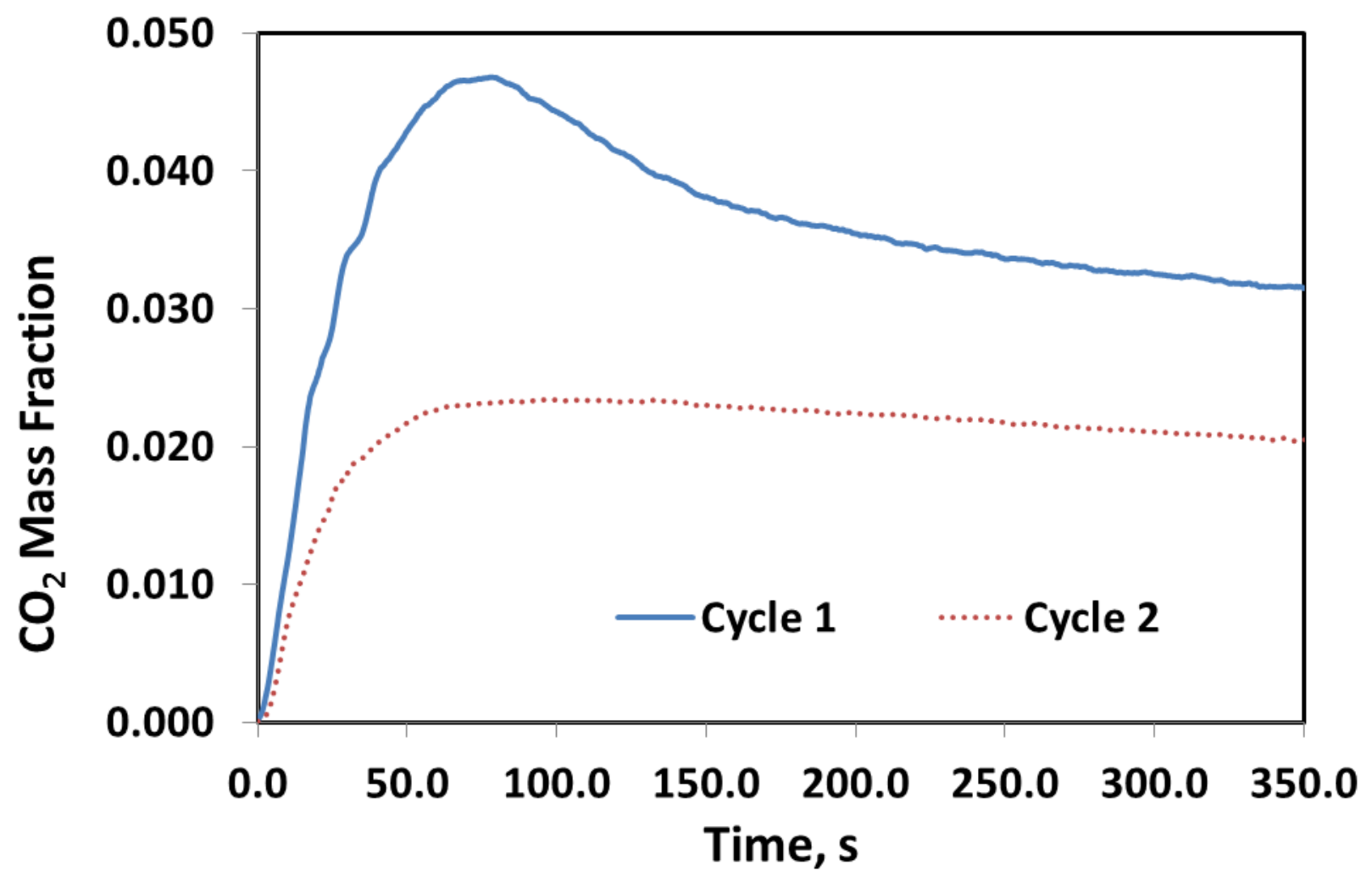

Figure 6. Comparison of Cycle 1 and Cycle $2 \mathrm{CO} 2$ production data 


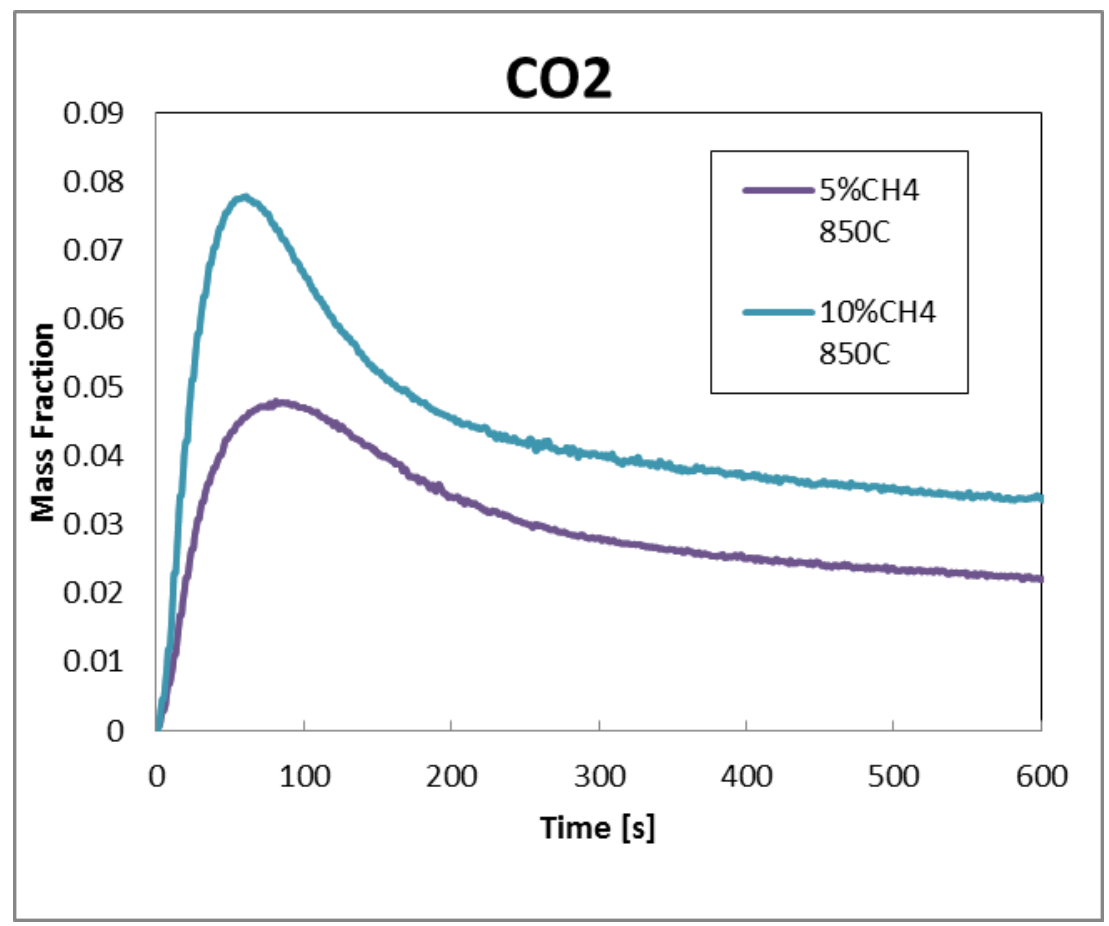

Figure 7 FSB_CO2 multiple cycles 


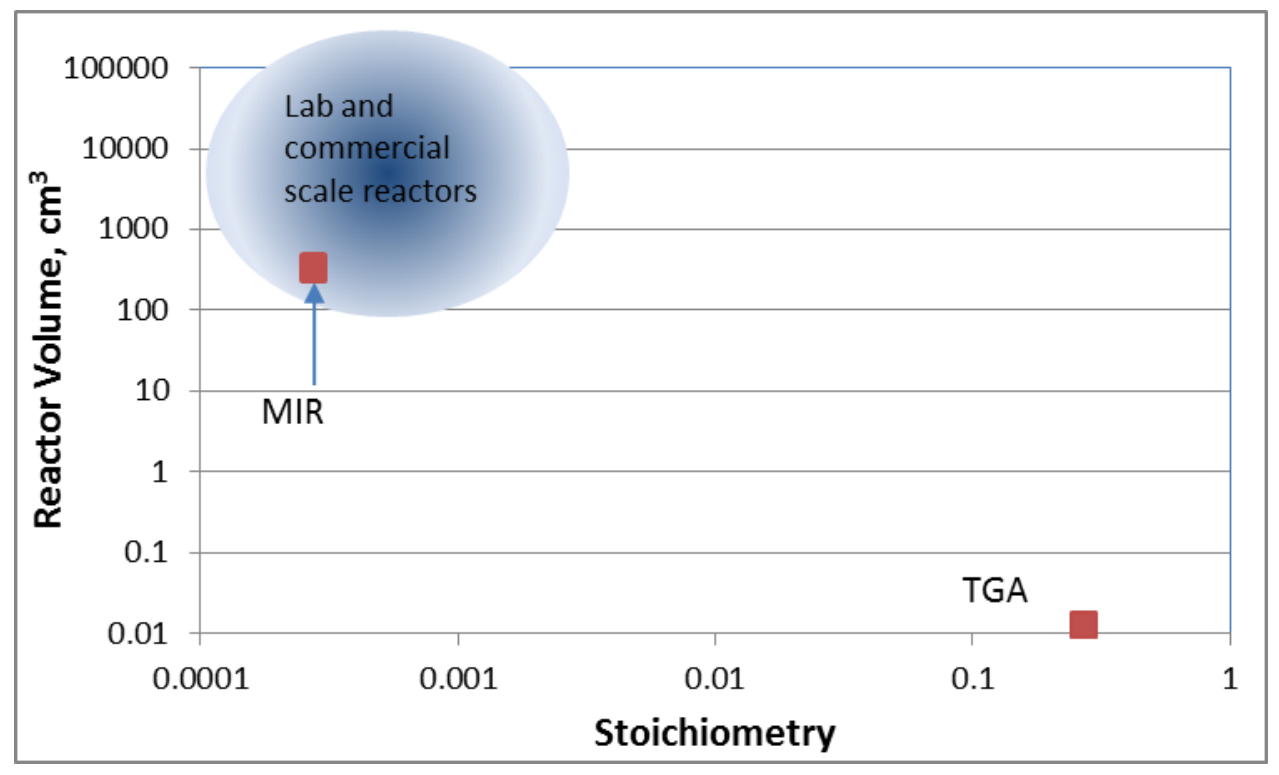

Figure 8 Test Reactor scales 

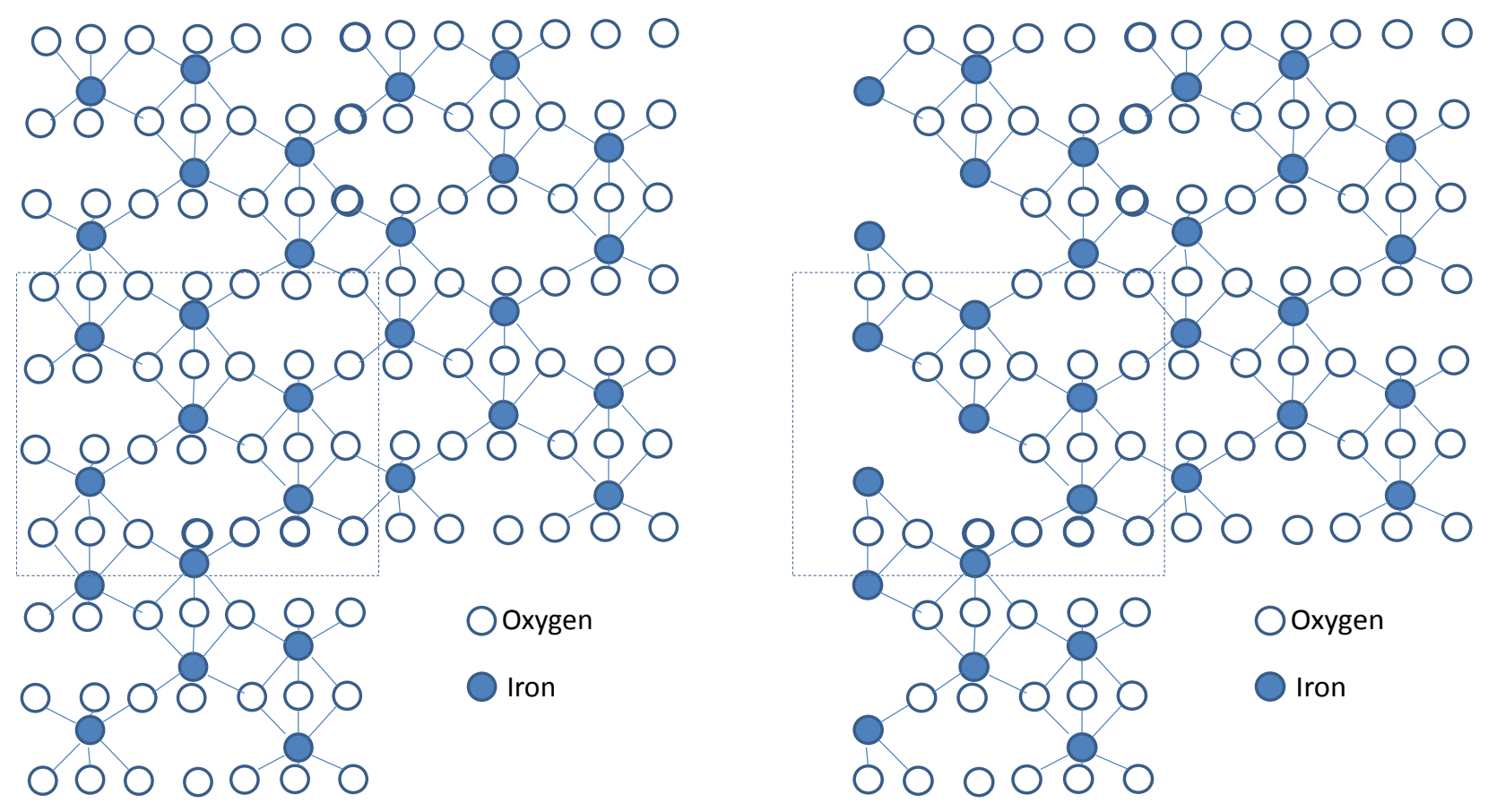

Figure 9. Fe2O3 surface prior to reduction and after partial reduction of the surface (adapted from[35]). 


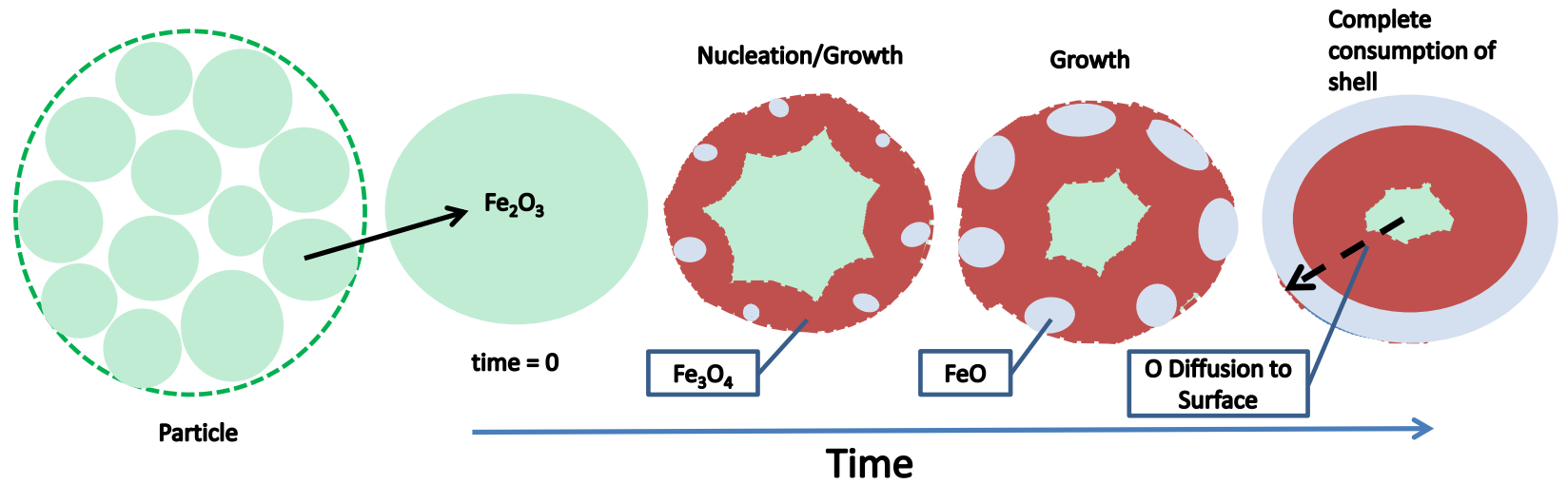

Figure 10 Particle model concept. 


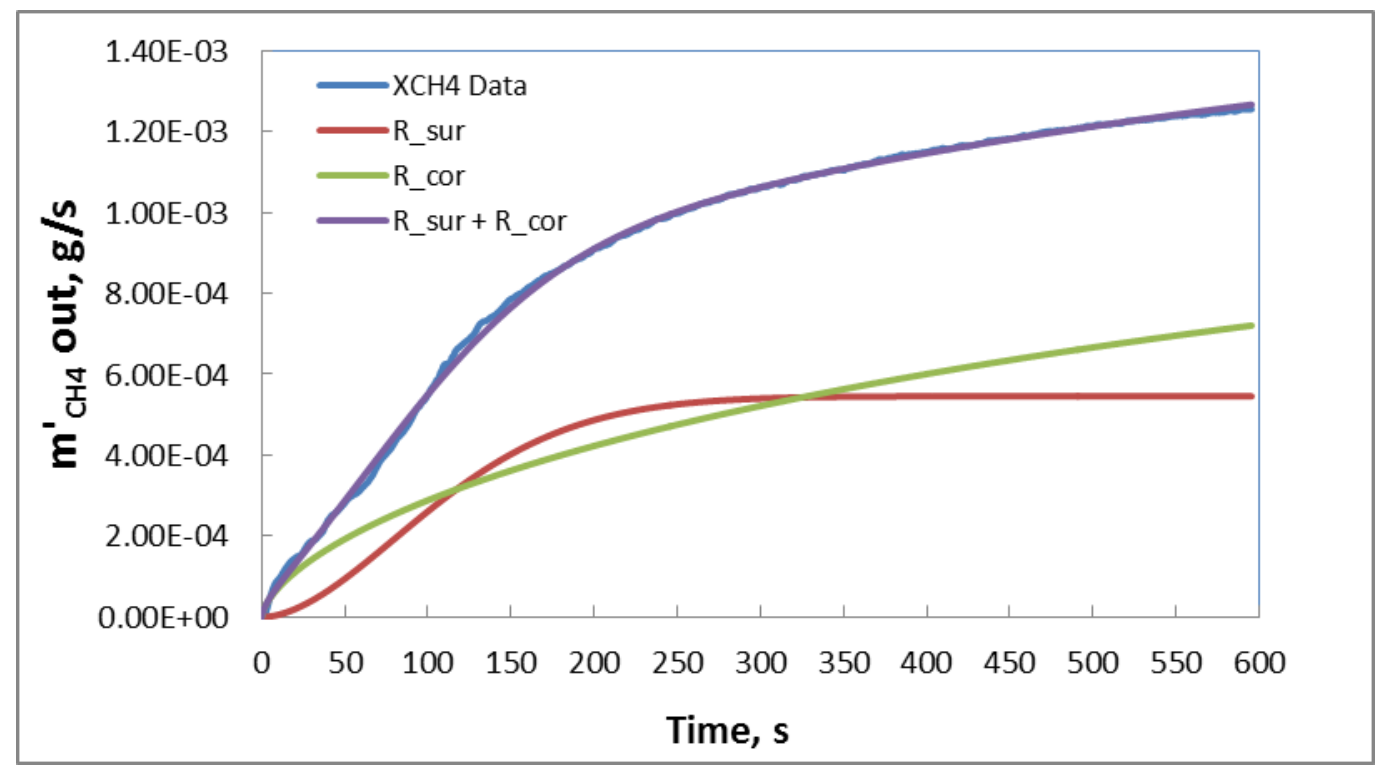

Figure 11. Example plot of $\mathrm{CH}_{4, \text { out }} / \mathrm{CH}_{4 \text {,in }}$ comparing data and model fit for Case 5 


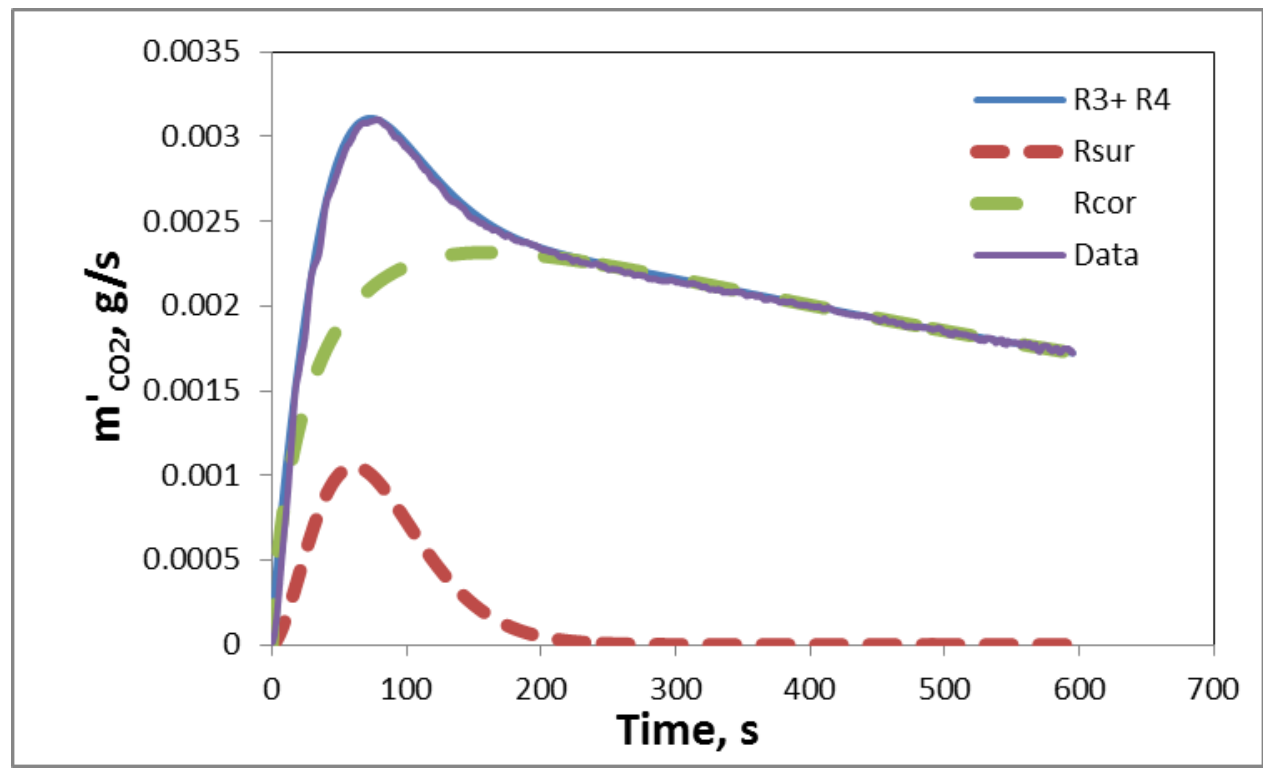

Figure 12. Example data showing $\mathrm{CO} 2$ exit gas and model fit data for Case 5 


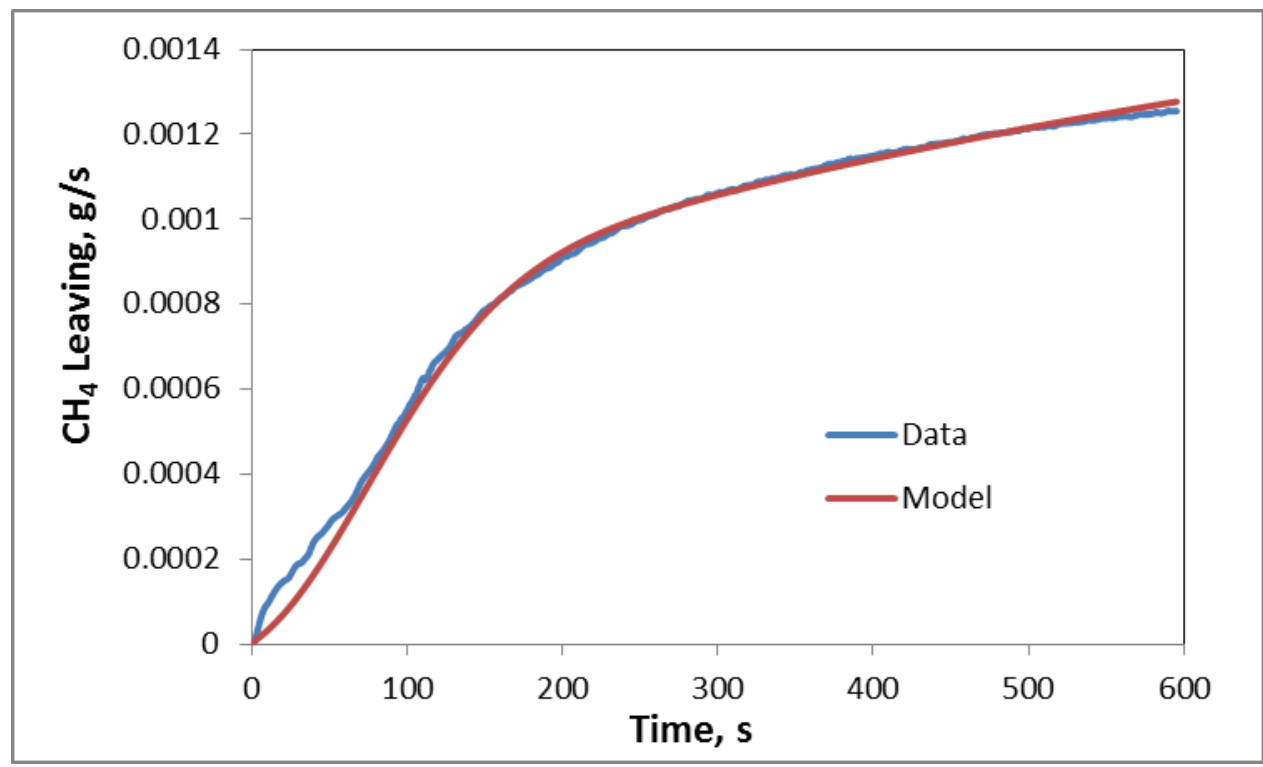

Figure 13. Comparison between model and data for $\mathrm{CH}_{4}$ leaving reactor for Case 5 


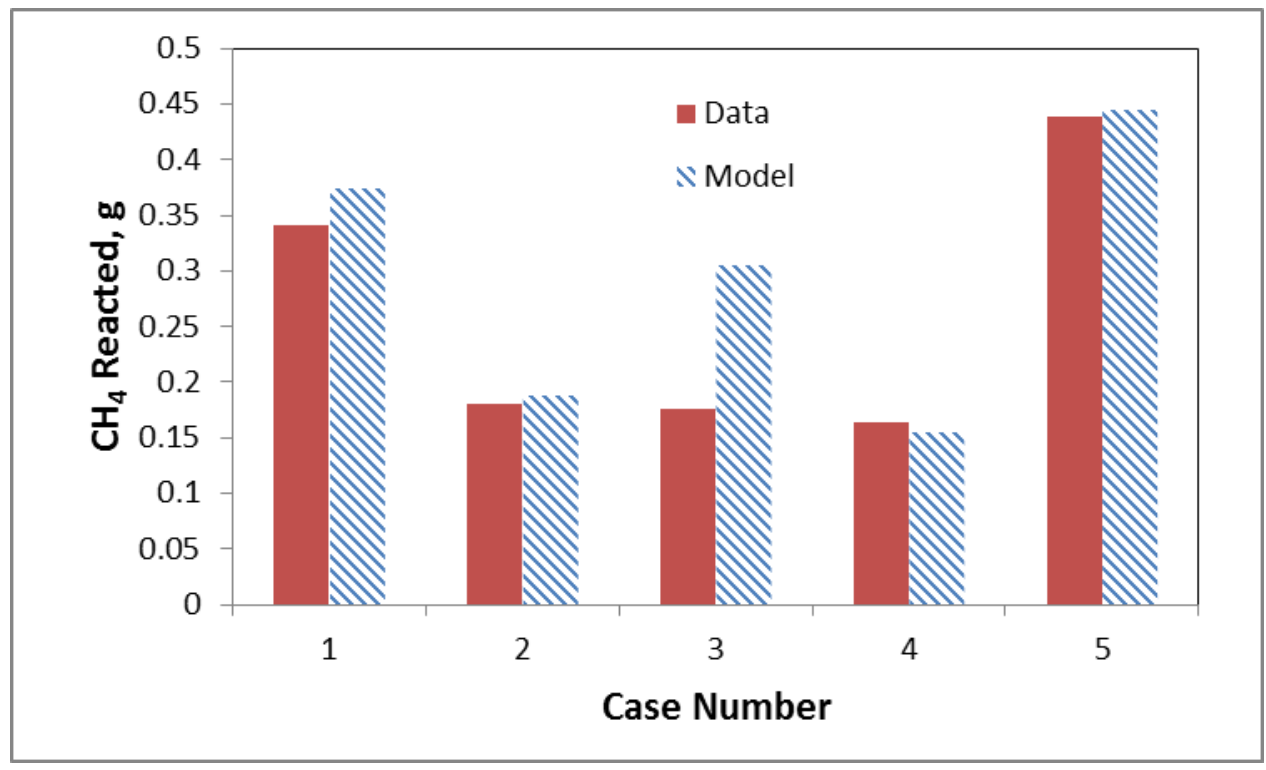

Figure 14. Comparison of $\mathrm{CH} 4$ reacted for model versus data 


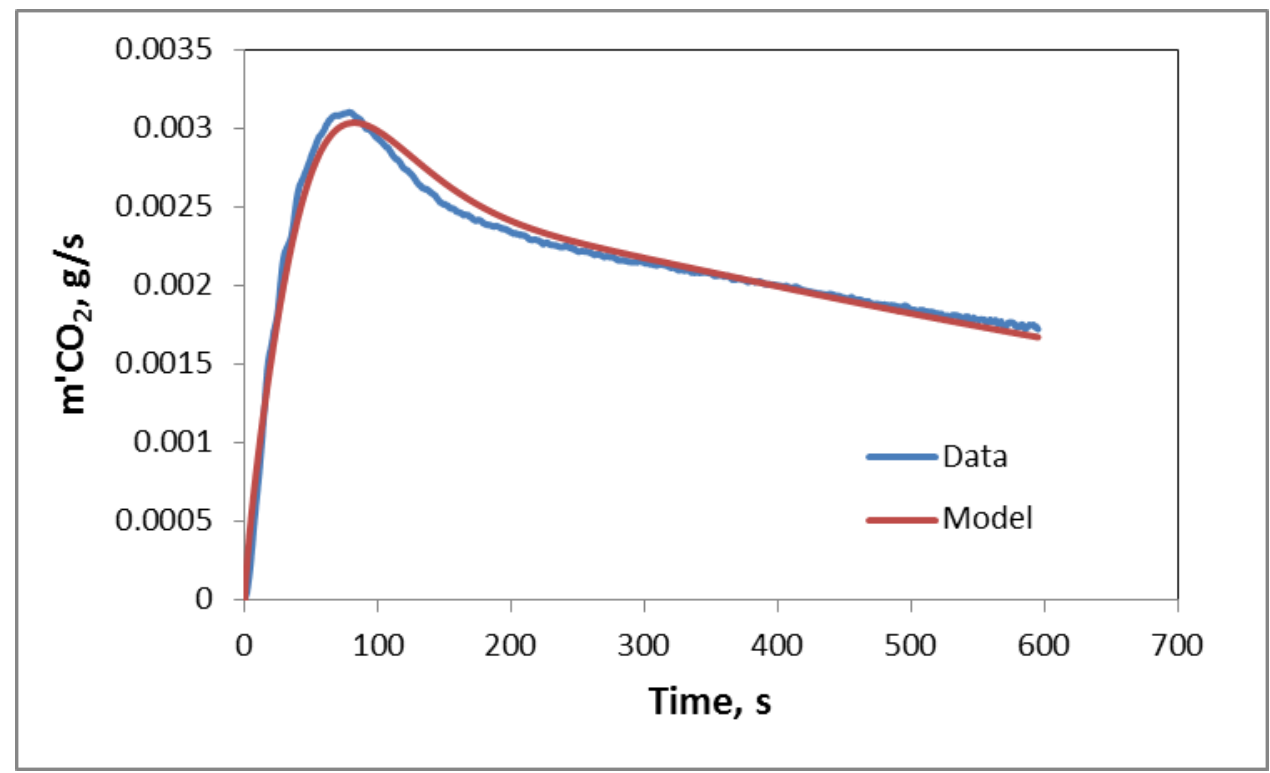

Figure 15. Rate of $\mathrm{CO} 2$ leaving reactor for Case 5 


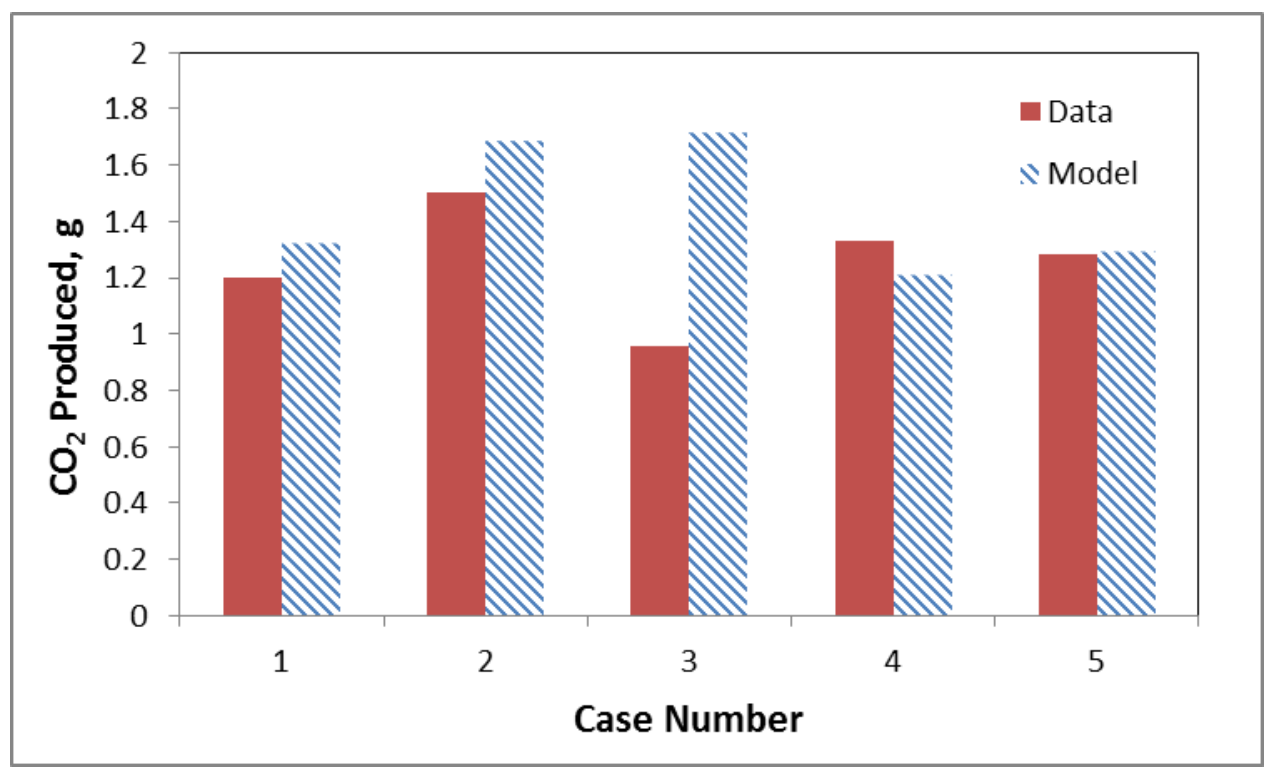

Figure 16. CO2 Produced during experiment 